\title{
Distribution of Elements in Iron-Manganese Formations in Bottom Sediments of Lake Onego (NW Russia) and Small Lakes (Shotozero and Surgubskoe) of Adjacent Territories
}

\author{
Vera Strakhovenko ${ }^{1,2, *}$, Dmitry Subetto ${ }^{2,3,4}$, Ekaterina Ovdina ${ }^{1,2}$, Natalia Belkina ${ }^{2}(\mathbb{D}$ and \\ Natalia Efremenko ${ }^{2}$ \\ 1 V.S. Sobolev Institute of Geology and Mineralogy, Siberian Branch of the Russian Academy of \\ Sciences (RAS), 3Akad. Koptyug Pr., 630090 Novosibirsk, Russia; ovdina@igm.nsc.ru \\ 2 Northern Water Problems Institute of the Karelian Research Centre, Russian Academy of Sciences, \\ 50 Alexander Nevsky Pr., 185030 Petrozavodsk, Russia; subetto@mail.ru (D.S.); bel110863@mail.ru (N.B.); \\ efremna@mail.ru (N.E.) \\ 3 Department of Geography, Herzen State Pedagogical University of Russia, 48 Moika Emb., \\ 191186 Saint-Petersburg, Russia \\ 4 Institute for Water and Environmental Problems, Siberian Branch of the Russian Academy of Sciences (IWEP \\ SB RAS), 1, Molodezhnaya St., 656038 Barnaul, Russia \\ * Correspondence: strahova@igm.nsc.ru
}

Received: 17 March 2020; Accepted: 12 May 2020; Published: 14 May 2020

\begin{abstract}
The morphology and mineralogical and geochemical compositions of the freshwater ferromanganese formations (FMF) of Lake Onego (NW Russia) and small lakes located in its catchment area were studied. The lake waters, bottom sediments and FMF were analyzed by a set of modern methods of geochemistry, mineralogy, and crystal chemistry (powder X-ray diffraction, IR spectroscopy, electron microscopy, ICP-MS analysis, atomic absorption, etc.). A detailed description of the microscopic structure in comparison with the geochemical characteristics of the FMF provides new information on the role of biota in the formation and behavior of individual elements at various stages in the nodule formation process. This study shows the homogeneous composition of microconcretions-only manganese or only ferruginous-in bottom sediments throughout the entire water area of Lake Onego and the rhythmic structures of the nodules, formed by macro- and microlayers with mineralized microbiota. The layers are composed of either crystalline Mn mineral phases (pyrolusite, rhodochrosite) or crystalline Fe mineral phases (siderite, goethite). The separation of $\mathrm{Mn}$ and Fe mineral phases in the nodules proceeded during their formation and diagenesis. The examined chemical and mineral compositions, textures, and structures of the nodules are a testament to the hydrogenic source of their ore substance and the formation of FMF is controlled primarily by redox environments at the water-sediment interface.
\end{abstract}

Keywords: Lake Onego; small lakes; NW Russia; iron-manganese formations; bottom sediments; geochemistry; mineralogy; Late Holocene

\section{Introduction}

The study of ferromanganese formations (FMF) from the bottom of modern water bodies (including lakes, seas, and the World Ocean) with the involvement of a wide range of modern analytical methods is very relevant today. FMF mining from the lakes of Karelia in NW Russia was very active during Peter the Great's era (the end of the 17th and beginning of the 18th century) and was of great importance in 
those days for the Russia. Currently, deposits of ferromanganese nodules (FMN) and crusts (FMC) of the World Ocean are of practical importance since they accumulate significant amounts of basic and rare metals as well as rare earth elements. However, ores from lakes are also a significant natural resource, the potential of which is not fully appreciated. Crusts, nodules, and microconcretions formed by iron and manganese oxyhydroxides with different geochemical and mineral compositions represent iron-manganese ore deposits in lakes, oceans, and seas [1-3]. According to the work of L.V. Kuleshevich [4], lake ores can be divided by morphological features into intooolitic (different sizes), crustal, spongy, and coinlike types. Oolitic ores are divided according to the size of the rounded nodules (oolites) into beams $(1-2 \mathrm{~cm})$, peas $(0.3-1 \mathrm{~cm})$, fractions $(0.1-0.3 \mathrm{~cm})$, and gunpowder (up to $0.1 \mathrm{~cm})$. Sometimes, concretions with a flat shape appear, called coin ores.

FMF have been studied for over 100 years throughout history, but some fundamental questions regarding their genesis remain debatable. Numerous studies of micro- and macroconcretions from seas and oceans and a comparison of their compositions within individual polygons and stations showed that they differ in their chemical composition and primarily in the ratio of $\mathrm{Mn} / \mathrm{Fe}$, the content of trace elements (including rare earth element (REE) and in the magnitude of Ce anomalies, but are similar in their mineral composition and morphology [5,6]. For FMF from freshwater lakes, such studies have not yet been done.

The most-studied modern FMF of lakes are Fe-Mn crusts and concretions from the bottom sediments of Lake Baikal [7-11], and FMF in the bottom sediments of small lakes, which are prevalent within the range of the Baltic Crystalline Shield [12,13].

Investigations into the mechanisms of lake bog ore formation were sufficiently detailed [1,14-18]. The catchment area of Lake Onego and its small lakes, according to limnological zoning, belongs to the subdistrict of iron-silica-humus accumulation, where surface waters are significantly enriched with Fe and Si and lake-marsh ores are formed in reservoirs. In some publications, FMC formation is associated with both physical and chemical processes $[14,16]$ and, in others, with the activity of micro-organisms $[19,20]$. It is likely that these two groups of processes run in parallel and in close connection with each other.

A detailed description of microscopic structures in comparison with the geochemical characteristics of the FMF of Lake Onego and small lakes located in its catchment area provides new information on the role of biota in their formation, and the behavior of individual elements at various stages of the nodule-formation process. In some articles by Och L. M. et al. [10,11], an examination of the bottom sediments of Lake Baikal showed that the formation of the upper layer must have been caused by early diagenetic processes during the mineralization of organic matter in the sediment. Oxygen concentrations in the bottom waters are $>0.36 \mathrm{mmol} \cdot \mathrm{L}^{-1}$ all year round, and the low content of $\mathrm{C}_{\text {org }}$ allows a high penetration depth of $\mathrm{O}_{2}$ into the sediment. Therefore, $60 \%$ to $75 \%$ of the gross sedimentation of $C_{\text {org }}$ is aerobically mineralized. The oxidizing capacities of $\mathrm{NO}_{3}{ }^{-}$and $\mathrm{SO}_{4}{ }^{2-}$ are low (due to low fluxes), thus implementing Fe(III) and $\mathrm{Mn}(\mathrm{IV})$ as the most important electron acceptors for the anaerobic mineralization of $C_{\text {org }}[10,11]$. Some articles state that nodules that precipitated from water that are located on the surface of lake sediments are more enriched in $\mathrm{Mn}$, while Fe is predominant in buried ones [21-25]. The mobility of iron is also associated with the formation of authigenic iron silicates in the interaction of oxyhydroxides with amorphous biogenic silica. In connection with these processes, the value of $\mathrm{Mn} / \mathrm{Fe}$ during oxidative diagenesis usually increases and reaches 2-10, while, during accumulation, it does not exceed 2-2.5 (Fe-Mn crusts, sedimentation Fe-Mn nodules). With the exhaustion of oxygen in suboxidative diagenesis, the mobility of $\mathrm{Mn}$ increases significantly due to the reduction in $\mathrm{Mn}^{4+}$ in the composition of $\mathrm{MnO}_{2}$ during the oxidation of organic matter. The diffusion of dissolved $\mathrm{Mn}^{2+}$ up to the region where free oxygen and nitrates or organic matter are present leads to the oxidation of $\mathrm{Mn}^{2+}$ and the deposition of manganese oxides, leading to a sharp increase in its contents, where the $\mathrm{Mn} / \mathrm{Fe}$ ratio usually exceeds 10 . The growth of the $\mathrm{Mn} / \mathrm{Fe}$ ratio is accompanied by an increase in the rate of formation of manganese microconcretions. An increase in the rate of microconcretion formation and a low redox potential of the environment do not contribute to the 
accumulation of elements (Ce, Fe group, REE, Th) [6]. For the FMF of Lake Baikal, the data show the upper Fe-Mn layer formed at the lowermost part of the oxygen penetration depth as a dynamic pattern, moving upward with the accumulating sediments. Thus, the reductive dissolution of Mn(IV) occurred at a lower margin. Upwardly diffusing $\mathrm{Mn}$ (II) was oxidized with $\mathrm{O}_{2}$, forming the upper boundary of $\mathrm{Fe}-\mathrm{Mn}$ accumulation. The buried Fe-Mn layers were immobilized within the sediment and underwent slow reductive dissolution, mainly driven by the anaerobic oxidation of $\mathrm{CH}_{4}$. The process leading to the detachment of the "active" Fe-Mn layer from the top redox interface is not unambiguously clear. However, we suggest a cyclical pattern where the burial of an Fe-Mn layer is accompanied by the generation of a new enrichment at the $\mathrm{O}_{2} / \mathrm{Mn}$ (II) redox boundary, which is subsequently nourished by the slowly dissolving old layer [10].

The purpose of our study was to study the specific features of the formation and occurrence of micro- and macroconcretions from Lake Onego and the small lakes (Shotozero and Surgubskoe) in its catchment area, and to estimate the role of the biogenic factor in the concentration of matter during FMF formation.

\section{Materials and Methods}

The object of our research is the Holocene bottom sediments of Lake Onego and the small lakes in its catchment area (Shotozero and Surgubskoe). Lake Onego $\left(61^{\circ} 42^{\prime} \mathrm{N}, 35^{\circ} 25^{\prime} \mathrm{E}\right)$ is the second largest freshwater lake in Europe, located in a deep tectonic depression at the junction of the Baltic (Fennoscandian) Crystalline Shield and Paleozoic sedimentary rocks of the Russian Platform. The catchment area is ca $62,800 \mathrm{~km}^{2}$, and the surface area is ca $9720 \mathrm{~km}^{2}$ [25]. Numerous publications are devoted to the geological structure and development history of Lake Onego and its basin [26-32]. The northern part of the catchment area of Lake Onego is composed of Precambrian crystalline rocks (granites, gneisses) that are resistant to abrasion processes, as well as deeply metamorphosed volcanogenic and sedimentary rocks of the Lower Proterozoic. In the south, within the limits of the Russian Plate, Vendian and Devonian sandy clay deposits are widespread. In many areas, a cover of Quaternary sediments (interglacial, continental, and marine formations of the Early, Middle, and Late Pleistocene, which are intensively destroyed by erosion) hides crystalline rocks. The average thickness of the Quaternary deposits increases from 6-8 $\mathrm{m}$ in the north to $10-20 \mathrm{~m}$ in the east of the region, and in its southern part, especially in the zone of connection of the shield and plate, it reaches 30-40 m, and sometimes 80-100 m [25].

The two studied small lakes-Lake Shotozero $\left(61^{\circ} 45^{\prime} \mathrm{N}, 33^{\circ} 05^{\prime} \mathrm{E}\right)$ and Lake Surgubskoe $\left(61^{\circ} 54^{\prime} \mathrm{N}\right.$, $34^{\circ} 06^{\prime}$ E) - are located within the catchment area of the River Shuya, which flows into the Petrozavodsk bay of Lake Onego (Figure 1). Lake Shotozero is located in the middle of the river basin. Shuya flows through it, and the catchment area of Lake Shotozero reaches $5540 \mathrm{~km}^{2}$. Lake Surgubskoe is located in the lower part of the river basin (Konchezersk group of lakes). Its catchment area is $408 \mathrm{~km}^{2}$. Most of the catchment area of Lake Shotozero is composed of Archean granite-gneiss complexes. The shungite-carbonate-shale layer of the horizon is located on the territory of the catchment area of lake Onega, with diabases and gabbrodiabases. Among extensive granite-gneiss fields, metamorphosed sedimentary and sedimentary-volcanogenic deposits are found. Rapakivi-type granites and quartzites, which are interbedded with diabases, dolomites, limestones, and shales, represent the coastal complex. The catchment of Lake Surgubskoe is composed of rocks belonging to the Lower and Upper Proterozoic, mainly basalts with interlayers of shungite-bearing deposits, tuff shales, sandstones, and conglomerates $[25,33,34]$. Quaternary sediments within the catchment area of Lake Surgubskoe are practically absent, and Precambrian rocks come to the surface.

The waters of the studied lakes are formed among well-washed Quaternary sediments in highly swampy terrain. The waters of Lake Onego are characterized by low mineralization (39-46 mg/L) and are chemically represented by $\mathrm{Ca}-\mathrm{HCO}_{3}{ }^{-}$. Their oxygen content is close to $100 \%$ saturation. The lake is oligotrophic [25]. The largest bays (Kondopoga and Petrozavodsk) of Lake Onego are anthropogenically influenced, and have mesotrophic status [35]. According to their chemical 
composition, Lake Shotozero's waters belong to the $\mathrm{Ca}-\mathrm{Mg}$ hydrocarbon group and are mesotrophic $(11 \mathrm{mg} / \mathrm{L})$. The waters of Lake Surgubskoe belong to the $\mathrm{Ca}-\mathrm{HCO}_{3}{ }^{-}$group and are mesotrophic ( $39 \mathrm{mg} / \mathrm{L}$ ). The maximal depth of Lake Onego is $127 \mathrm{~m}$ with an average depth of $30 \mathrm{~m}$. The maximal depth of Lake Shotozero is $10 \mathrm{~m}$ with an average depth of $3 \mathrm{~m}$. The maximal depth of Lake Surgubskoe is $24 \mathrm{~m}$ with an average depth of $14 \mathrm{~m}$ (Figure 1 and Table 1) [35]. According to limnological zoning, the studied territory of Karelia belongs to a subregion of iron-silica-humus accumulation, where surface waters are substantially enriched in $\mathrm{Fe}$ and $\mathrm{Si}$, and suspended forms are predominantly amorphous and crystalline Fe hydroxides and silicates $[3,36,37]$.

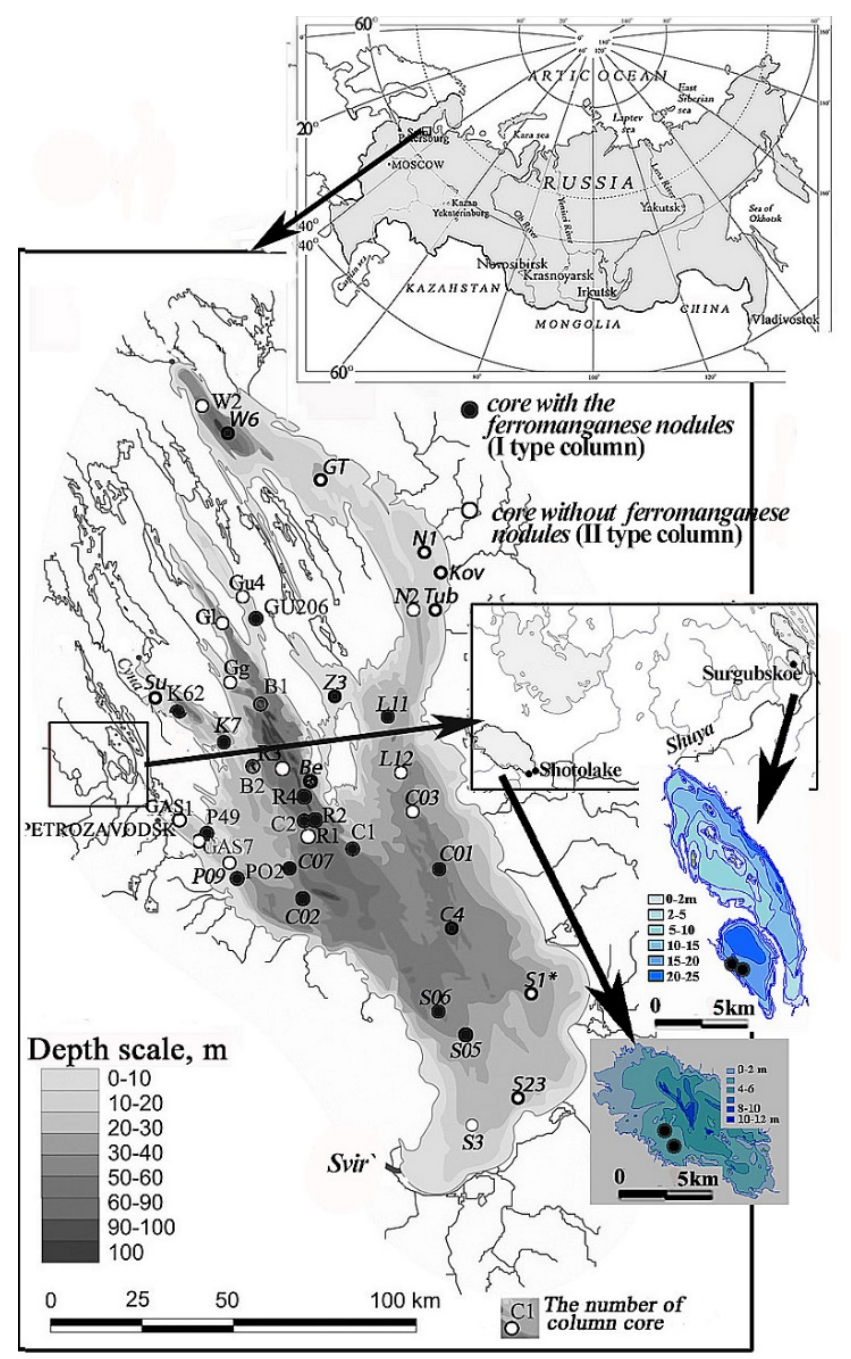

Figure 1. A map of the depths of Lake Onego, the small lakes within its catchment area (Lake Shotozero and Lake Surgubskoe) and the position of the spots of selection in bottom sediment columns.

Table 1. Chemical composition of waters of the studied lakes.

\begin{tabular}{ccccccccccccc}
\hline Lake & $\mathbf{H C O}_{3}{ }^{-}$ & $\mathbf{S O}_{4}{ }^{2-}$ & $\mathbf{C l}^{-}$ & $\mathbf{C a}^{2+}$ & $\mathbf{M g}^{2+}$ & $\mathbf{N a}^{+}$ & $\mathbf{P}_{\text {total }}$ & $\mathbf{F e}$ & $\mathbf{M n}$ & $\boldsymbol{\Sigma} \boldsymbol{\mu}$ & $\mathbf{O}_{2}$ & $\mathbf{p H}$ \\
\hline Onego & 21.3 & 5.2 & 1.7 & 5.7 & 2.2 & 2.0 & 12 & 0.07 & - & 38.8 & 96 & 7.4 \\
Shotozero & 4.8 & 1.1 & 1.4 & 1.7 & 1.0 & 1.2 & 15 & 0.71 & 0.1 & 11.7 & 93 & 6.6 \\
Surgubskoe & 19.6 & 6.8 & 1.4 & 5.4 & 2.7 & 2.4 & 17 & 0.03 & - & 39 & 87 & 6.9 \\
\hline
\end{tabular}

$\mathrm{P}_{\text {total }}$ : total phosphorus, $\Sigma \mu$ : total mineralization of waters, $\mathrm{pH}$ : the value of alkalinity of acidity.

The research subject is the FMF of bottom sediments of Lake Onego and small lakes within its catchment area (Lakes Shotozero and Surgubskoe). FMC in the bottom sediments of Lake Onego were 
first mentioned in the work of K.K. Gilzen in 1918, and the processes of ore formation in the lakes of Karelia were considered in studies by N. I. Semenovich in the 1950-1960 s [21].

Samples of Lake Onego's sediment sequence $(0-100 \mathrm{~cm})$ were collected with Bikeraand Gaun samplers in different parts: (1) Big Onego, B1, B2, and Be stations; (2) Small Onego, L11 and L12 stations; (3) Central Onego, C1, C2, C4, C01, C04, and C07 stations; (4) South Onego, S06, S05, S1* and S23 stations; (5) Unitsky bay, GU-206 station; (6) Kondopoga bay, K 62 and Su stations, (7) Petrozavodsk bay, GAZ1, GAZ7, PO2, and P49 stations; (8) Povenetsky bay, W6, GT stations; (9) Zaonezhsky bay, N1, Kov, Tub stations, and in Lakes Shotozero and Surgubskoe (Figure 1, Table 2). Bottom sediment samples were collected aboard scientific vessel (S/V) Ecolog.

Table 2. Sampling locations, positions and depths of the Lake Onego and small lakes within its catchment area (Lake Shotozero and Lake Surgubskoe).

\begin{tabular}{|c|c|c|c|c|c|c|}
\hline \multirow{2}{*}{ Location } & \multirow{2}{*}{ Station } & \multicolumn{2}{|c|}{ Position } & \multirow{2}{*}{$\begin{array}{l}\text { Lake Depth } \\
\text { (m) }\end{array}$} & \multicolumn{2}{|c|}{$\mathrm{O}_{2}$, Saturation of Water $\%$} \\
\hline & & $\mathbf{N}$ & E & & $0.5 \mathrm{~m}$ & Near Bottom \\
\hline \multirow{7}{*}{ Big Onego } & B1 & 62,07264 & 34,87868 & 90 & 95 & 89 \\
\hline & B2 & 61,92688 & 34,83381 & 40 & 96 & 89 \\
\hline & $\mathrm{Be}$ & 61,89889 & 35,09685 & 83 & 95 & 81 \\
\hline & $\mathrm{R} 4$ & 61,86714 & 35,05595 & 120 & 96 & 85 \\
\hline & $\mathrm{R} 3$ & 61,94249 & 34,94996 & 105 & 95 & 79 \\
\hline & $\mathrm{R} 2$ & 61,7977 & 35,09918 & 80 & - & - \\
\hline & $\mathrm{R} 1$ & 61,75745 & 35,11869 & 65 & - & - \\
\hline \multirow{2}{*}{ Small Onego } & L11 & 62,03352 & 35,53754 & 39 & 96 & 88 \\
\hline & L12 & 61,89971 & 35,50037 & 39 & 96 & 77 \\
\hline \multirow{6}{*}{$\begin{array}{l}\text { Central } \\
\text { Onego }\end{array}$} & $\mathrm{C} 2$ & 61,79979 & 35,07079 & 80 & 95 & 77 \\
\hline & $\mathrm{C} 07$ & 61,66667 & 35,1001 & 61 & 95 & 77 \\
\hline & $\mathrm{C} 01$ & 61,68404 & 35,75638 & 66 & - & - \\
\hline & $\mathrm{C} 02$ & 61,58244 & 35,13867 & 43 & - & - \\
\hline & $\mathrm{C} 1$ & 61,63675 & 35,4711 & 59 & 96 & 88 \\
\hline & $\mathrm{C} 4$ & 61,47233 & 35,76277 & 57 & - & - \\
\hline \multirow{5}{*}{ South Onego } & S23 & 61,20895 & 36,22098 & 27 & - & - \\
\hline & S1 & 61,37038 & 36,17717 & 47 & 95 & 79 \\
\hline & S06 & 61,29898 & 35,79085 & 50 & 95 & 89 \\
\hline & S05 & 61,2167 & 35,90957 & 34 & 95 & 83 \\
\hline & S3 & 61,12048 & 35,94197 & 26 & 95 & 81 \\
\hline \multirow{5}{*}{$\begin{array}{l}\text { Petrozavodsk } \\
\text { Bay }\end{array}$} & GAS1 & 61,79207 & 34,41378 & 23 & 95 & 81 \\
\hline & GAS7 & 61,78533 & 34,46850 & 25 & - & - \\
\hline & P49 & 61,78083 & 34,54833 & 20 & 95 & 81 \\
\hline & P09 & 61,68132 & 34,71616 & 39 & - & - \\
\hline & $\mathrm{PO} 2$ & 61,67244 & 34,70825 & 40 & - & - \\
\hline \multirow{3}{*}{$\begin{array}{c}\text { Povenetsky } \\
\text { Bay }\end{array}$} & GT & 62,59708 & 35,10240 & 32 & - & - \\
\hline & W2 & 62,79239 & 34,62687 & 104 & 95 & 82 \\
\hline & W6 & 62,74215 & 34,50858 & 23 & 95 & 88 \\
\hline \multirow{2}{*}{$\begin{array}{l}\text { Zaonezhsky } \\
\text { Bay }\end{array}$} & N1 & 62,43375 & 35,71667 & 20 & 95 & 84 \\
\hline & Kov & 62,30883 & 35,79513 & 22 & - & - \\
\hline \multirow{2}{*}{ Unitsky Bay } & GU4 & 62,33024 & 34,77625 & 30 & 96 & 85 \\
\hline & GU206 & 62,31055 & 34,82111 & 39 & - & - \\
\hline $\begin{array}{c}\text { Lake } \\
\text { Shotozero }\end{array}$ & $\begin{array}{c}\text { Fe-Mn } \\
\text { nodules }\end{array}$ & 61,737286 & 33,075805 & 3 & 93 & - \\
\hline $\begin{array}{c}\text { Lake } \\
\text { Surgubskoe }\end{array}$ & $\begin{array}{l}\text { Fe-Mn } \\
\text { nodules }\end{array}$ & 61,939910 & 34,127327 & 2 & 87 & - \\
\hline $\begin{array}{c}\text { Lake } \\
\text { Shotozero }\end{array}$ & Fe-Mn crust & 61,737292 & 33,075911 & 5 & 93 & - \\
\hline
\end{tabular}

Note: “-"—no data. 
Core sediment samples were studied layer by layer at intervals of $1-2 \mathrm{~cm}$. After visual lithological and stratigraphical descriptions of the sediment columns in situ, studies of pore water features $(t$, $\mathrm{pH}, \mathrm{Eh}, \mathrm{CO}_{2}, \mathrm{O}_{2}$ ) were carried out directly on board S/V Ecolog. Samples were studied using a set of geological, geochemical, petrographical, and mineralogical methods at the multielement Isotopic Research Center of the Siberian Branch of RAS in Novosibirsk. Major (Al, Fe, Ca, Mg, K, and $\mathrm{Na}$ ) and trace $(\mathrm{Cd}, \mathrm{Pb}, \mathrm{Cu}, \mathrm{Zn}, \mathrm{Mn}, \mathrm{Cr}, \mathrm{Ni}, \mathrm{Co}, \mathrm{V}, \mathrm{Hg}, \mathrm{Be}, \mathrm{Ba}, \mathrm{Sr}$, and $\mathrm{Li}$ ) elements in the bottom sediments were determined by atomic absorption with the use of flame and electro thermal atomization (Solar M6, Thermo Electron Corporation, Waltham, MA, USA; 139 samples). FMN mineral composition was determined by powder X-ray diffraction (21 samples). Samples were studied with an ARL X'TRA diffractometer (Thermo Electron Corporation, Waltham, MA, USA, CuK $\alpha$ radiation). Concentrations of trace elements were determined using ICP-MS analysis that was carried out on an ELEMENT high-resolution mass spectrometer (Finnigan MAT, Thermo Electron Corporation, Waltham, MA, USA) (21 samples). FMN morphology, phase, and chemical compositions of the sediments were studied using a MIRA 3 Tescan scanning electron microscope (Tescan, Brno-Kohoutovice, Czech Republic). The current modification of the equipment uses an Si (Li) energetic detector (OXFORD mark, Oxford Instruments, Abingdon, UK). The method allows quantitative chemical analysis to be carried out on microvolumes. The INCA Energy 300 program (Labspec 5) was used for quantitative chemical analysis with reference standards (2145 definitions of mineral compositions). Raman spectra were derived using a Horiba LabRamHR800 system (Labspec 5) and an Olympus BH-2 microscope (Olympus America, Inc., Melville, NY, USA) with 100× objective. An excitation wavelength of $532 \mathrm{~nm}$ was used with a power of $10 \mathrm{~mW}$. Scattered light was dispersed using a holographic grating with 1800 grooves per millimeter. The spectral resolution was about $3.0 \mathrm{~cm}^{-1}$. Raman spectra were recorded from 100 to $1300 \mathrm{~cm}^{-1}$ (accumulation time: 5 and 10s). Raman spectra were excited by Nd: YAG laser. Calibration was carried out using a silicon wafer $\left(520.6 \mathrm{~cm}^{-1}\right)$. Studies were conducted at room temperature. Analytical work was performed at the Analytical Center for Multielement and Isotope (Sobolev Institute of Geology and Mineralogy, Siberian Branch of the Russian Academy of Sciences, Novosibirsk, Russia). The accuracy and validity of the obtained analytical data were confirmed by an analysis of standard samples. Its results agreed with the certified contents of their elements. The chemical features of the water and upper samples of the bottom sediment (loss on ignition (LOI) $t$ $+550{ }^{\circ} \mathrm{C}$, zone sequence, $\mathrm{C}_{\text {org }}$, pigments, humic and fulvic acids, $\mathrm{N}-\mathrm{NH}_{4}{ }^{+}, \mathrm{N}_{\text {org }}, \mathrm{P}_{\text {lab. }}, \mathrm{P}_{\text {total, }}, \mathrm{Fe}, \mathrm{Mn}, \mathrm{Eh}$, and $\mathrm{pH}$ ) were studied at the Hydrogeochemistry and Hydrogeology and Paleolimnology laboratories of the Northern Water Research Institute of the Karelian Research Centre of RAS, Petrozavodsk, Russia.

\section{Research Results}

\subsection{Core stratification of the Bottom Sediment of Lake Onego, Morphology and Mineral Composition of FMC Lakes}

An analysis of the composition and geochemical features of upper bottom sediments of the cores Lake Onego (upper 0-50 cm of sediment) showed that they belong to two different types [38,39]. Well water circulation in the lake, which provides deep-water composition near the bottom $(20 \mathrm{~cm}$ above the bottom sediment), is generally scarcely different from the contents of the whole water body in $\mathrm{O}_{2}, \mathrm{~N}_{\text {organic, }} \mathrm{P}$ and $\mathrm{Si}$ across all bottom sediment stations, and $\mathrm{Mn}$ and Fe in the first type of bottom sediment stations. In the columns of the bottom sediments of Lake Onego, due to the high amounts of $\mathrm{O}_{2}$ in the water (first type), there is an oxidized zone that is indicated by the brown of the uppermost layer of sediment. The oxidized zone (depth of about 5-35 cm) ends in a in a thin layer of FMF (1-2 cm thick). FMF was formed at the boundary where the oxygen penetrated in sediment (dominated by high values of Eh from +300 to $+450 \mathrm{mV}$; Figure 2). FMF have a thinly layered texture. More deeply, along the sediment sequence, Eh becomes close to zero or negative, reaching $-18 \mathrm{mv}$, and the sedimentary environment becomes reductive. Below, homogeneous gray-green silt can be found, gradually compacted and replaced by gray, laminated (varved) clays. In homogeneous silt, numerous microlayers (bands) of black (pyrolusite composition), green (vivianite), and cream (rhodochrosite, 
siderite) can be observed (Figure 3). Their number and distribution patterns in different columns of bottom sediments vary significantly.

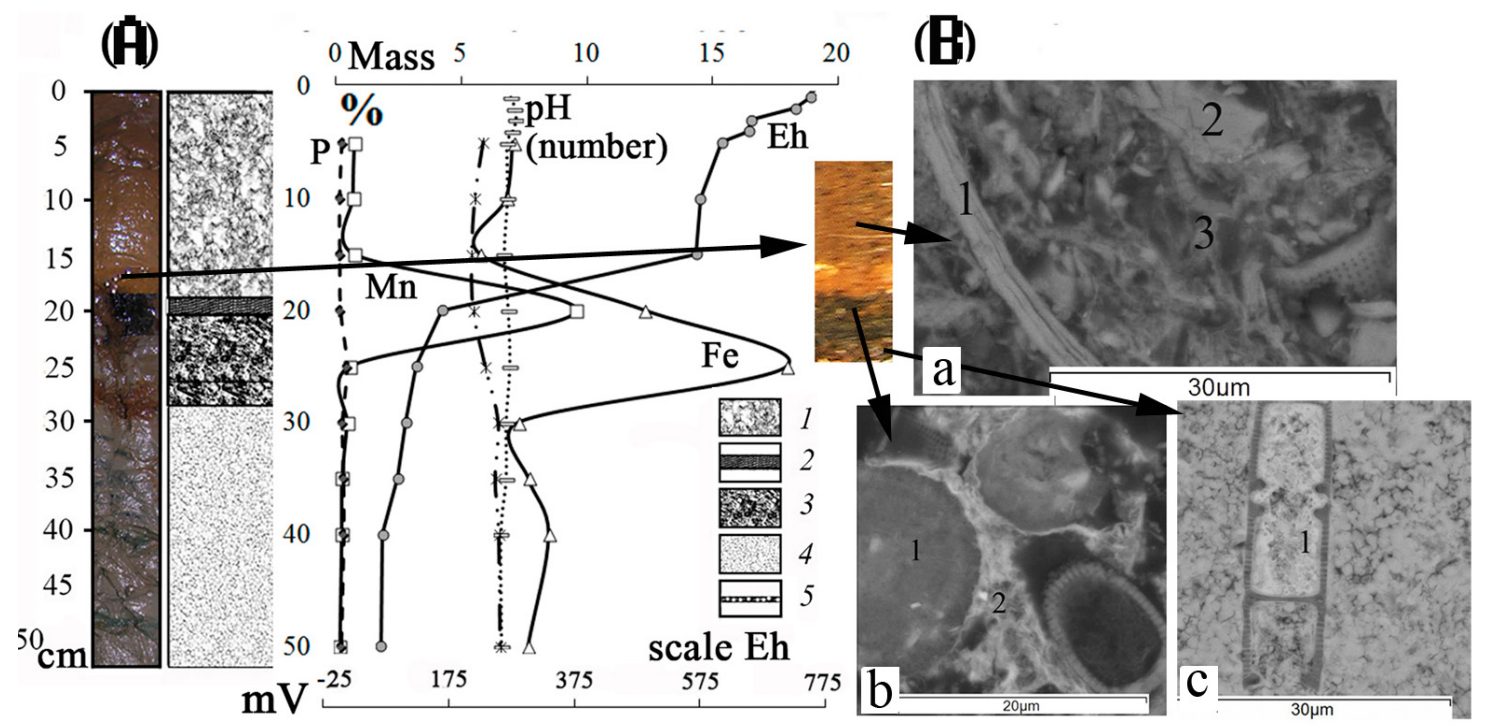

Figure 2. (A) Structure of first type of sediment cores from Lake Onego and the distribution of $\mathrm{Fe}, \mathrm{Mn}, \mathrm{Al}, \mathrm{P}$ (mass \%), pH (number) (on the upper X-axis), Eh (mVat the bottom of the X-axis): 1-pelitic mud of oxidized zone; 2-black ore crust (Mn mineral phases); 3-chocolate-colored ore crust (mineral phase of $\mathrm{Fe}$ ); 4-homogeneous grayish-green silt; 5-black, gray and green-colored microlayers (vivianite, rhodochrosite, siderite, pyrolusite) in the homogeneous grayish-green silt; (B) photo of oxidized zone with FMF made using an electron microscope (MIRA-3): a-the oxidized zone 1-muscovite, 2-quartz, 3-association of Fe-illite with diatom leaves; $b$-the Mn-bearing layer: 1-Mn microconcretion, 2-association of Fe-illite with diatom leaves; c-Fe-bearing layer: 1-goethite, shell-spherical collomorphic formations with various morphology and degree of crystallinity.

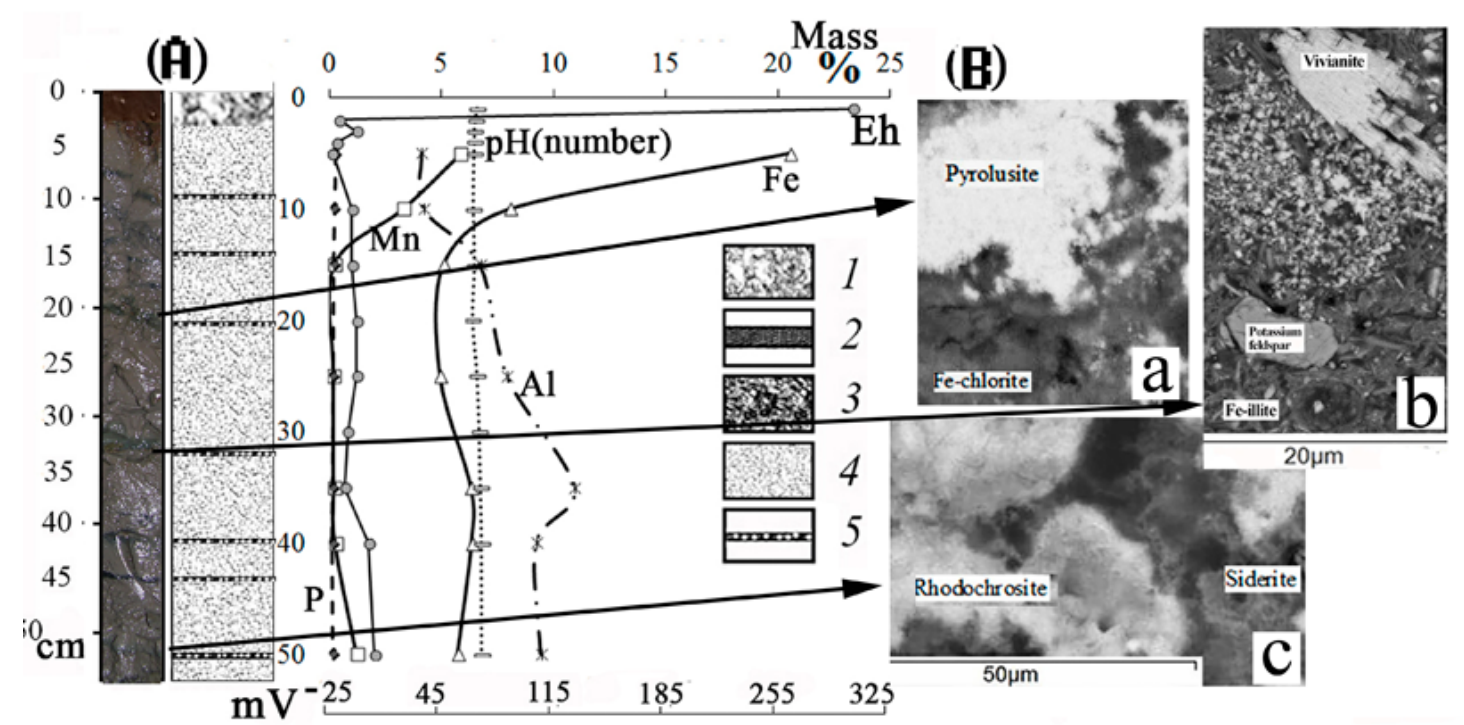

Figure 3. (A) Structure of second type of sediment cores from Lake Onego and the distribution of Fe, Mn, $\mathrm{Al}, \mathrm{P}$ (mass \%), pH (number) (on the upper X-axis), Eh (mVat the bottom of the X-axis): 1-pelitic mud of oxidized zone; 2 -homogeneous grayish-green silt; 3 -black, gray and green-colored microlayers (vivianite, rhodochrosite, siderite, pyrolusite) in the homogeneous grayish-green silt; (B) photo of black, green and gray-colored microlayers: $a$ - pyrolusite; $b$-vivianite; $c$-rhodochrosite, siderite in the homogeneous grayish-green silt made using an electron microscope MIRA-3. 
Under the conditions of a free $\mathrm{O}_{2}$ shortage (second-type stratification columns), the redox boundary is located in the sediment near the water-sediment boundary. The oxidized zone is less than 1-2-cm thick (Figure 3). Soluble $\mathrm{Mn}^{2+}$ and $\mathrm{Fe}^{2+}$ ions migrate from the lower layers of the sediment to the water-sediment boundary, which is confirmed by significantly higher Fe and Mn contents in bottom water at the column sampling sites. In the stratification of the second type of sediment cores from Lake Onego, there are no FMF and, under a thin oxidized layer, there is homogeneous silt similar to that present in the lower parts of the sections in the first type of sediment cores. Columns like the bottom sediments of the first type can be observed in all regions of Lake Onego (Figure 1).

In all sediment columns of the first type, the FMF layer has a zonal structure: the finest uppermost $(<3 \mathrm{~mm}$ ) Mn-bearing layer, and a thinner (up to $2 \mathrm{~cm}$ ) Fe-bearing layer underlying it. The Mn-bearing layer is composed of isolated Mn microconcretions in association with diatom valves, Fe illite or Fe chlorite, and grains of terrigenous minerals (Figure 4a). All Mn microconcretions, no matter their size, have a spherical shape, a radial structure complicated by an internal, sometimes asymmetric structure, and consist of a core and shells surrounding them (often X-ray-amorphous; Figure 4b). Manganese microconcretions are slightly enriched with $\mathrm{Ba}$ in comparison with the host deposits (Figure 4c).The microlayer below the manganese microlayer is composed of goethite of shell-spherical collomorphic formation with various morphology types and degrees of precipitated crystallinity, from microconcretions to fine-needle, leafy crystals, and pseudomorphs of organic residues, in association with the same minerals and diatom valves as in Mn microconcretions. Fe microconcretions are spherical, with a concentrically zonal structure that most often has an irregular shape. Moreover, goethite sometimes forms pseudomorphs on various substrates (diatoms, chlorite flakes, and plant remains) or a curd mass composed of fine grains $(\sim 1 \mu \mathrm{m})$. When determining the mineral composition of Mn microconcretions by X-ray diffraction analysis, burnessite and pyrolusite were diagnosed within the samples of this microlayer (Figure $5 \mathrm{a}$ ).

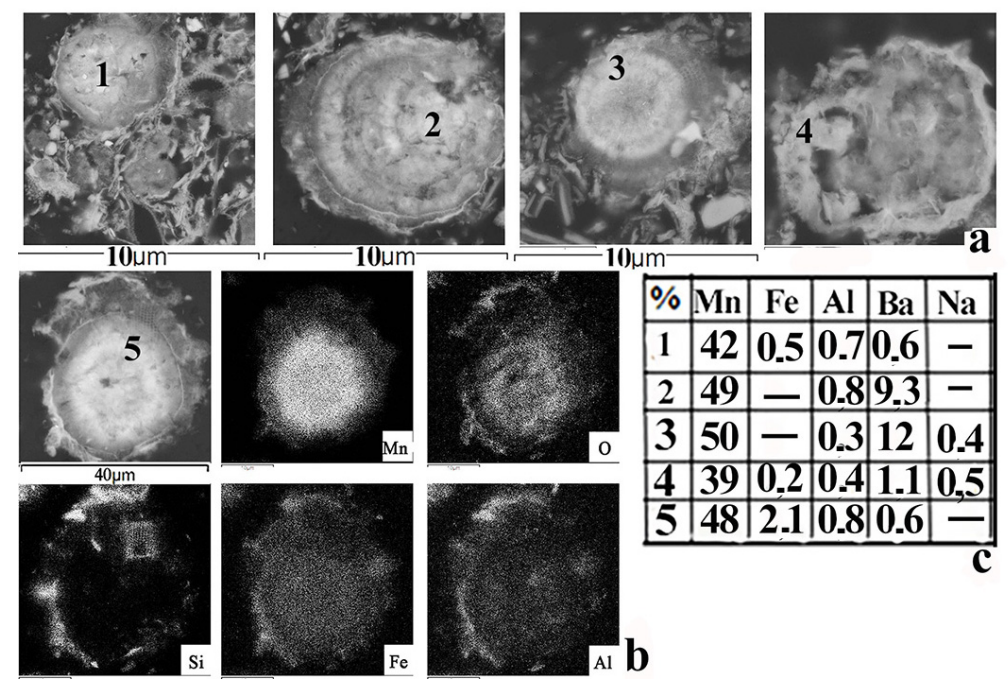

Figure 4. Photo of manganese microconcretions from different regions of Lake Onego (a) made using an electron microscope MIRA-3; (b) elemental areal concentration distribution scan (Fe, $\mathrm{Mn}, \mathrm{Ba}, \mathrm{Si}, \mathrm{Al}$, $\mathrm{Na}, \mathrm{K}, \mathrm{Co}$, etc.) in Mn, microconcretion from Onego Lake made with SEM; (c) table of contents of the main elements in manganese microconcretions.

A microanalysis of the chemical composition (SEM) of various layers of Mn microconcretions, as well as their analysis with Raman microprobe spectroscopy, showed the presence of various interlayering manganese mineral phases: in addition to those mentioned above, there are also pyrolusite, todorokite, and vernadite. According to 189 analyses, the variation of elements in them is as follows (\%): Fe (0.2-12.6), Mn (10.4-52.6), Ba (1.9-12.6), O (30.2-46.0), Na (0.0-1.2), Al (0.2-6.6), $\mathrm{Ca}(0.0-6.0)$, and total (56.1-98.2) (Figure 5b). Their structures vary in the composition of interlayer 
cations and in the number of water molecules bonded to layers of $\left[\mathrm{MnO}_{6}\right]$ octahedrals [40]. Among the rock-forming minerals, there are quartz, plagioclase, potassium feldspar, illite, chlorite, muscovite, and X-ray amorphous phases of $\mathrm{SiO}_{2}$.

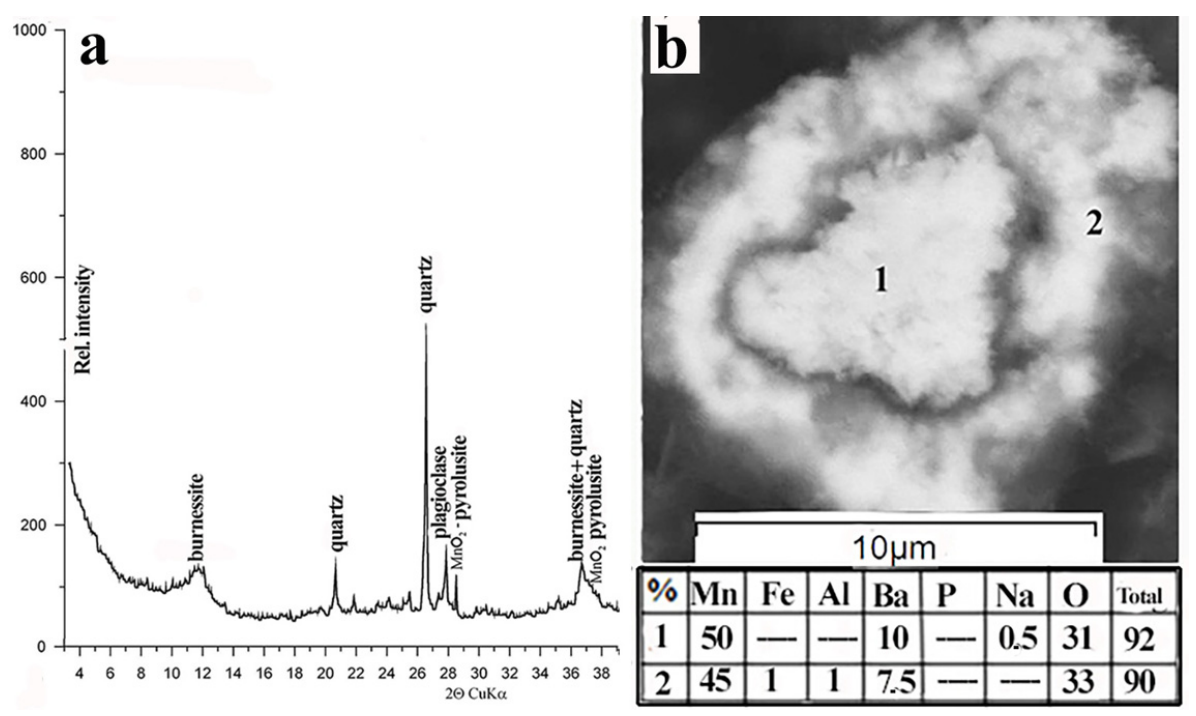

Figure 5. (a)-X-ray diffraction pattern of thin layer with manganese microconcretions from the core of bottom sediments of the Petrozavodsk Bay of Lake Onego: burnessit, pyrolyusite, quartz, plagioclase; (b) - photos taken using SEM and quantitative chemical analysis of manganese microconcretion: 1-central part, 2-with an external isolated border consisting of cotton-like plexuses of threads.

The determination of the mineral phases of Fe microconcretions and formations is rather difficult due to the presence of a large number of pseudomorphs of Fe hydroxides by organic remains, and the presence of poorly crystallized and X-ray-amorphous phases.

Part of the microconcretions is composed of crystalline goethite, according to studies by X-ray diffraction analysis (SEM). According to the data of 154 Fe phases, the variation of their elements is as follows (in \%): Fe (23-65), Mn (0-19), Ba (0-0.6), O (26.2-47.0), P (0.4-4.2), and total (55.1-100.2). An analysis of the triple composition diagram of FMF of Lake Onego was confirmed by data from an elemental area scan ( $\mathrm{Fe}, \mathrm{Mn}, \mathrm{Ba}, \mathrm{Si}, \mathrm{Al}, \mathrm{Na}, \mathrm{K}, \mathrm{Co}$, etc.) of the concentration distribution in microconcretions of Lake Onego with SEM (Figure 6).

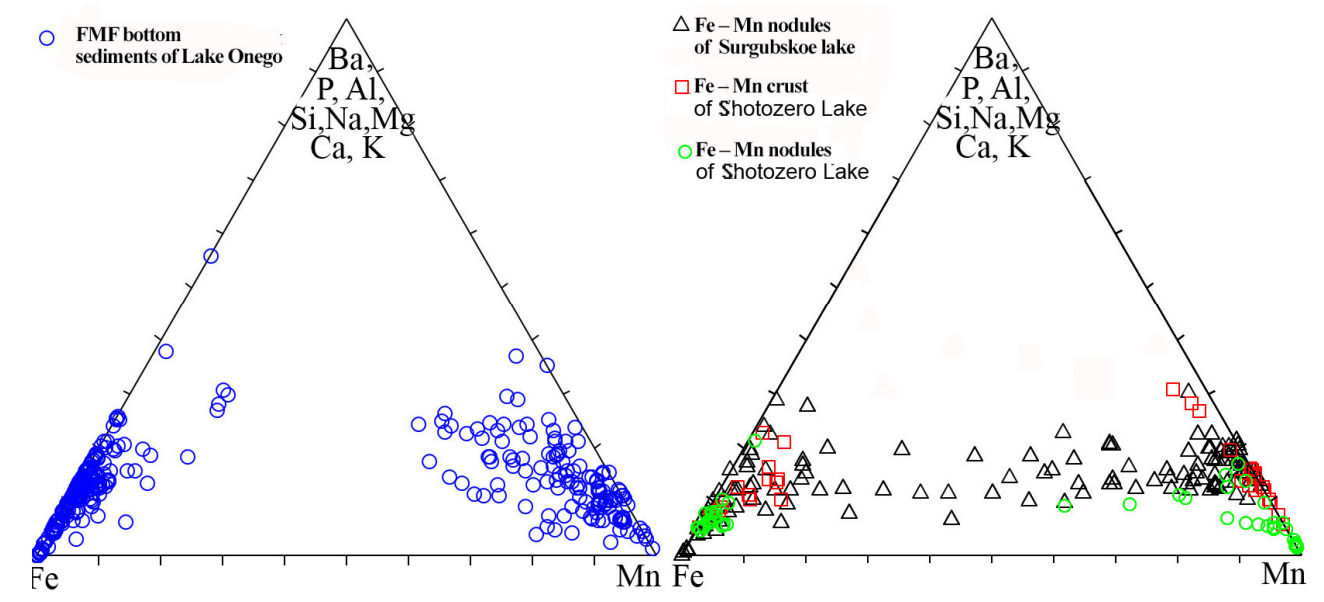

Figure 6. Triple diagram $\mathrm{Fe}-(\mathrm{Ba}+\mathrm{P}+\mathrm{Al}+\mathrm{Si}+\mathrm{Na}+\mathrm{Mg}+\mathrm{Ca}+\mathrm{K})-\mathrm{Mn}$ with the chemical compositions of Fe-Mn micro concretions from various wells of Lake Onego and the FM concretions and crusts of Lake Surgubskoye and Lake Shotozero. 
A clear predominance of one of the elements in the composition of microdamages $(<1 \mathrm{~mm})$ was revealed: only manganese or only ferruginous (Figures $4 \mathrm{~b}$ and $5 \mathrm{~b}$ ) was prevalent in the FMF along the entire water area of Lake Onega or in larger FMN (from $1 \mathrm{~mm}$ to $1 \mathrm{~cm}$ ) from the bottom sediments of Petrozavodsk bay, with the zonal distribution of isolated bands of Fe and Mn (Figure 7).
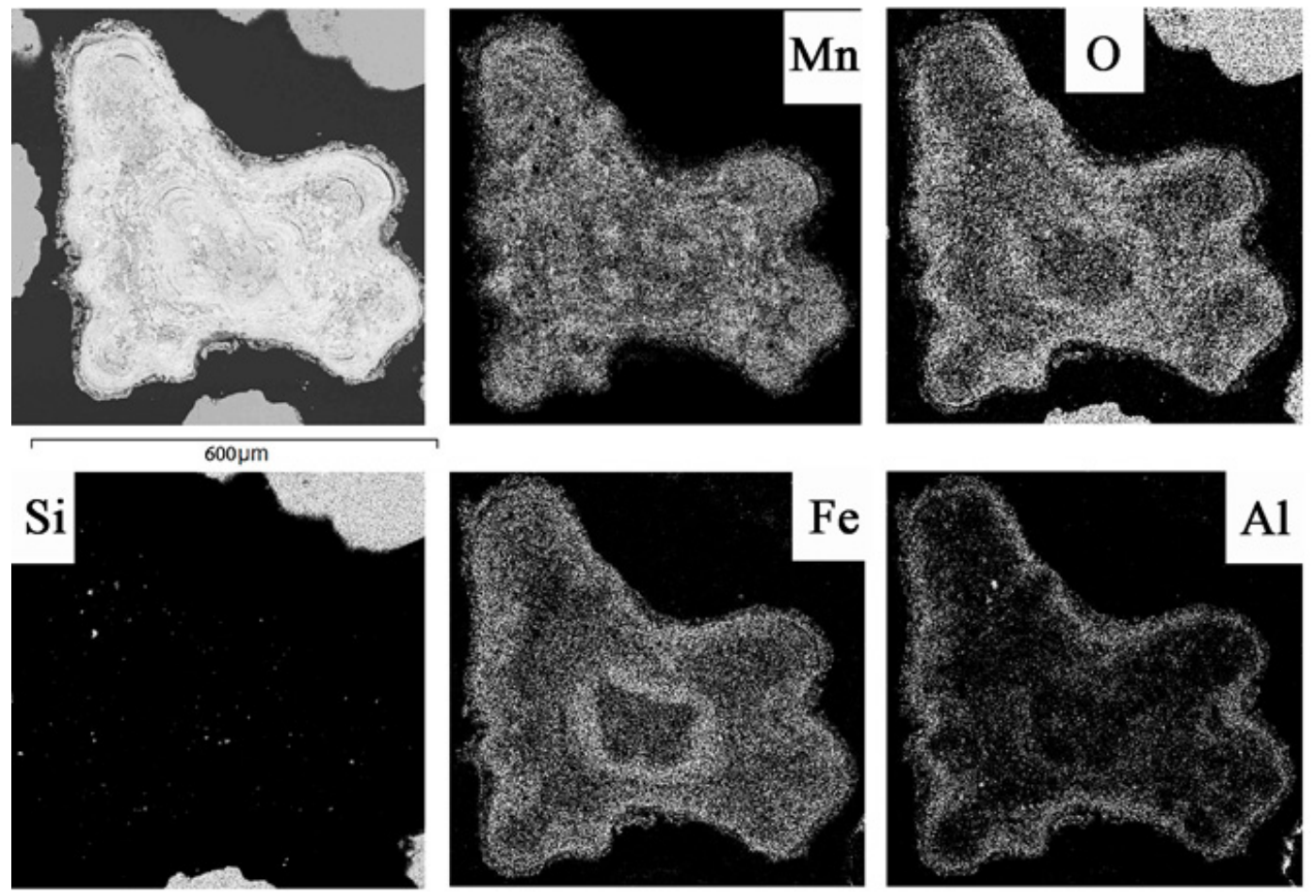

Figure 7. Photo micrographs (MIRA-3 electron microscope) of larger ferromanganese nodules (FMN) (from $1 \mathrm{~mm}$ to $1 \mathrm{~cm}$ ) from bottom sediments of the Petrozavodsk Bay with the zonal distribution of $\mathrm{Fe}$, $\mathrm{Mn}$ bands and the areal distribution of $\mathrm{Mn}, \mathrm{O}, \mathrm{Si}, \mathrm{Fe}$ and $\mathrm{Al}$ contents in them.

In the restored homogeneous silty clays, rhodochrosite and siderite were present in all studied sequences of deposits. The SEM study made it possible to establish that Mn-rich carbonates appear in the form of spherical shapes with a surface pattern. They form dispersed clusters, sometimes zonally, with separate zones of rhodochrosite and siderite, veins in the mass of satellite fiber formations of illite, chlorite, diatom valve fragments, terrigenous grains of quartz, feldspars, and muscovites of various size.

Sediment samples from Lakes Surgubskoye and Shotozero included coins (flat nodules) up to $10 \mathrm{~cm}$ in size, oolitic ores (legumes, peas, shot, powder) of spotty, uneven and rusty texture and a dark brown to black color. In addition to nodules, Fe-Mn crusts up to 10-cm thick with a thin, concentrically zonal texture, and with a large amount of branching and inclusions of nonmetallic minerals, individual earlier nodules or their fragments, consisting of either rhodochrosite or siderite, were selected in Lake Shotozero (Figure 8). All FMC lie on the bottom sediment surface (water-bottom sediment interface) or in the uppermost surface layer of sludge. The presence of a core is typical for most nodules, the role of which is played by a solid surface of any composition-compacted silty clay with quartz-feldspar composition and fragments of the preceding generation of nodules. Around the FMC core, there is an increase in the concentric layers of, at first, oxide-manganese hydroxides, then iron hydroxides, then manganese, and so on. The concentrically zonal structure of oolitic nodules is also significantly associated with the presence of zones with various densities (distinguished by color, relatively dense ones are darker). This is most likely due to the degree of crystallinity of the mineral phases of manganese and iron. When conducting an elemental areal scan of concentration distribution ( $\mathrm{Fe}, \mathrm{Mn}, \mathrm{Ba}, \mathrm{Si}, \mathrm{Al}, \mathrm{Na}, \mathrm{K}, \mathrm{Co}$, etc.) in these nodules using SEM, dense zones were mainly characterized 
by the homogeneous composition of either Fe (goethite) or Mn, with the constant presence of barium (burnessite, vernadite).

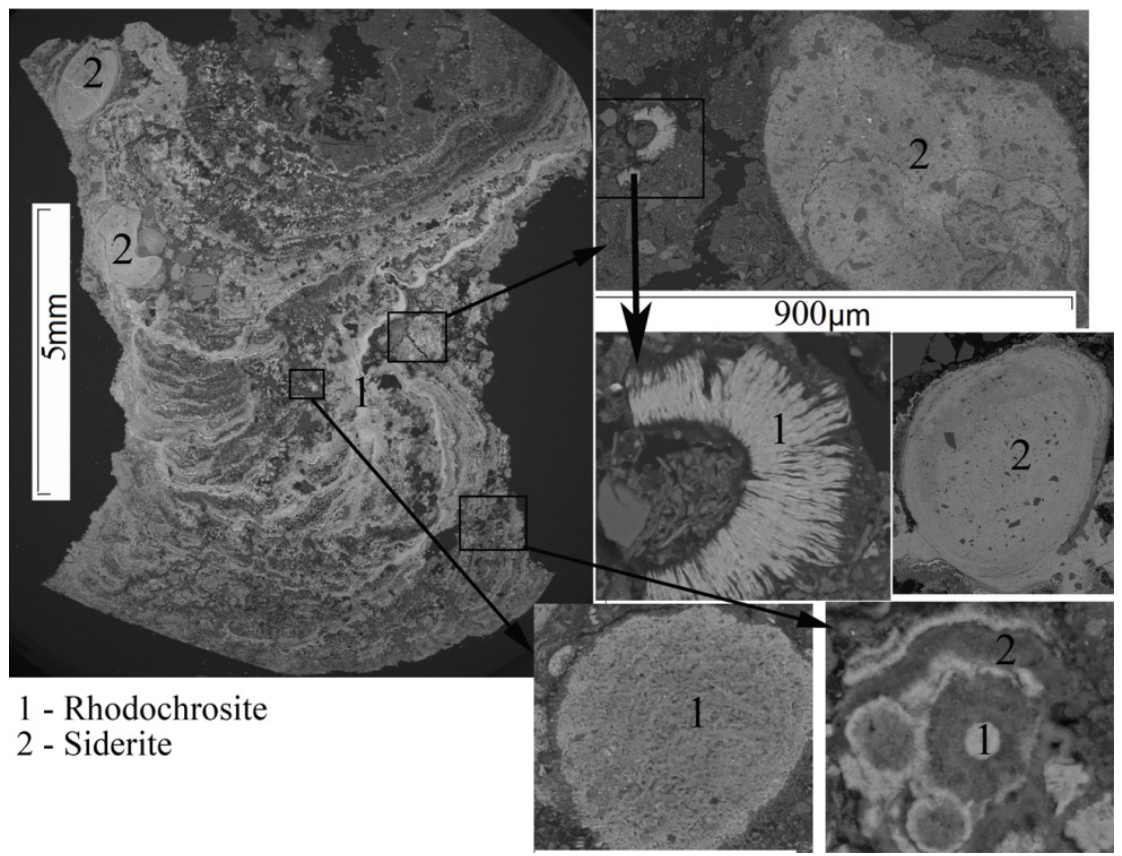

Figure 8. Photo micrographs (MIRA-3 electron microscope) of Fe-Mn crusts (from $3 \mathrm{~cm}$ to $10 \mathrm{~cm}$ ) from bottom sediments of Lake Shotozero with a zonal distribution of $\mathrm{Fe}$, Mn bands and individual earlier nodules or fragments of them consisting of either rhodochrosite or siderite.

In dense zones, structural details are hardly visible, but in loose ones, the constant presence of organic residues can be observed, mainly diatoms, as well as fragments of fossilized glycocalyx, both in Lake Shotozero (Figure 9a) and in Lake Surgubskoe (Figure 9b). Areas with layered structures similar to textures inherited from lithified organic matter relics consist exclusively of manganese compounds.

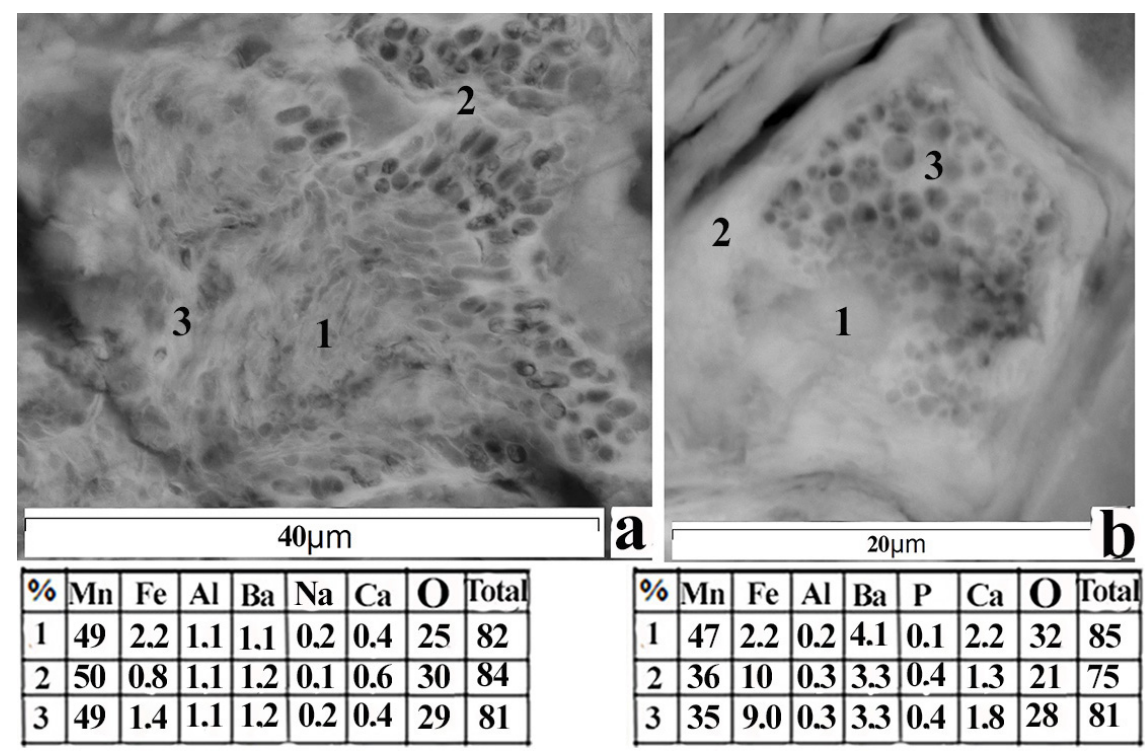

Figure 9. Photo, taken using SEM manganese central part of nodules with textures inherited from lithified relics of organic matter: (a)-FMN of Shotozero; (b)-FMN of Surgubskoe. 
When using SEM, sometimes a hollow shell-like structure of individual nodules can be observed. All coinlike (disk) nodules and Fe-Mn crusts of Lake Shotozero sediments have a zonal distribution of separate Fe and Mn zones. This was confirmed by data from elemental areal scanning of the concentration distribution ( $\mathrm{Fe}, \mathrm{Mn}, \mathrm{Ba}, \mathrm{Si}, \mathrm{Al}, \mathrm{Na}, \mathrm{K}, \mathrm{Co}$, etc.) in the nodules of Lakes Surgubskoe and Shotozero. During chemical composition analysis of FM nodules and crusts from these lakes, the constant presence of Ba and Fe in signifficant amounts in manganese zones was revealed, along with the presence of Mn and P impurities in the granular zones. The chemical composition of FM nodules from Lake Surgubskoe is as follows: granular zones (\%): Fe (24-67), Mn (0-21), Ba (0-0.5), O (28-42), $\mathrm{P}(0.5-2)$, and total (44-100); manganese zones (\%): Fe (1-35), Mn (38-52), Ba (4-12), O (27-48), P (0-1), and total (55-99).

The chemical composition of FM crusts from Lake Shotozero is as follows: iron zones (\%): Fe (37-58), Mn (0-6), Ba (0), O (28-39), P (0.5-2), and total (72-100); manganese zones (\%): Fe (0-3), Mn (33-55), Ba (1-8), O (30-42), P (0), and total (56-99). The chemical composition of FM nodules from Lake Shotozero is as follows: granular zones (\%): Fe (33-51), Mn (0-2), Ba (0), O (28-39), P (0.5-1), and total (61-96); manganese zones (\%): Fe (0-20), Mn (33-56), Ba (1-8), O (26-36), P (0), and total (60-99). Quite often, in the chemical composition of the FMC, the presence of $\mathrm{Si}, \mathrm{Al}, \mathrm{Na}$, and Ca is determined in contents from $0.2 \%$ to $6 \%$. Almost all nodules on the periphery are characterized by the formation of crusts composed of small grains of nonmetallic minerals: quartz, feldspars, muscovite, and chlorite. Sometimes, thin layers of nonmetallic minerals repeatedly occur within nodules.

\subsection{Geochemical Composition of Bottom Sediments and FMC of Lakes}

During the FMN formation, the enrichment of $\mathrm{Ba}, \mathrm{Mo} \mathrm{P}$ and Co occurred due to the lake water or element diffusion from underlying sediments (Figure 10). The content of $\mathrm{Ni}, \mathrm{Cd}, \mathrm{Zn}, \mathrm{Sb}$, and $\mathrm{Hg}$ remained almost at the same level as in the bottom sediments, with the exception of FMN of Petrozavodsk bay (Lake Onego) and Lake Surgubskoe, both of which are enriched with Ni and Zn. For other studied elements in FMN, concentrations decreased significantly compared to their level in the bulk sediment. The average content of REE in the FMF of different regions of Lake Onego did not significantly differ (varying from $\sim 147$ to $\sim 154 \mathrm{~g} / \mathrm{t}$ ), with the exception of REE contents in the FMN of Petrozavodsk bay $(364 \mathrm{~g} / \mathrm{t})$.

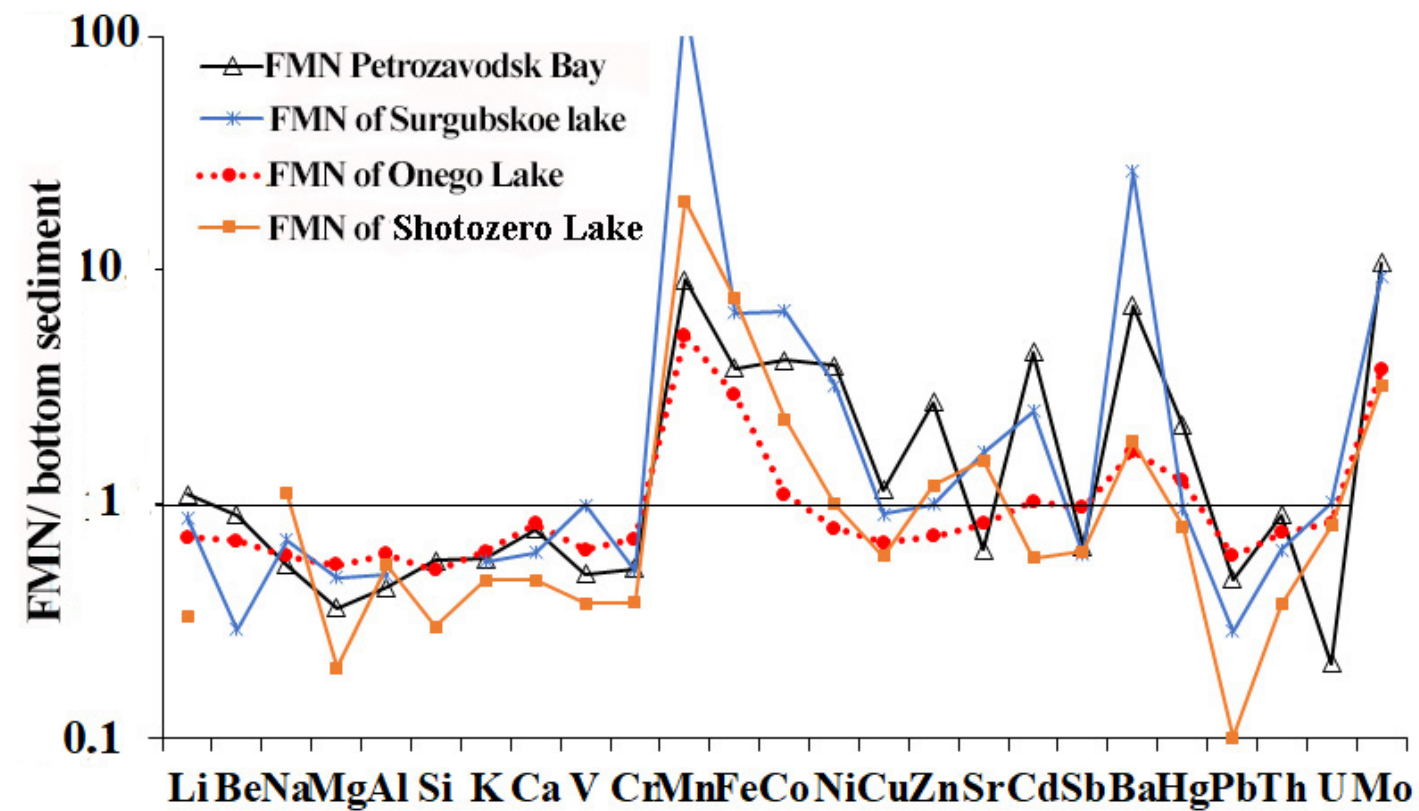

Figure 10. Element contents in FMN, gathered from various areas of Lake Onego/small lakes, normalized to the element concentrations in host (Lake Onego) or underlying (Lake Surgubskoe and Lake Shotozero) bottom sediments. 
Here, the maximal values of REE contents in the FMF of Lake Onego were observed, with average REE contents in FM crusts and nodules of Lake Surgubskoe, and Lake Shotozero close to them. The results of the average total REE contents in the studied samples and information on the main indicator ratios of lanthanides normalized to chondritis [41] are given in Table 3.

Table 3. The average total REE contents and basic values of stratified horizons normalized to chondritis of bottom sediments from different regions of Lake Onego (our data) and rocks from the water catchment area [25].

\begin{tabular}{|c|c|c|c|c|c|c|c|}
\hline Area of Lake Onego & $\Sigma R E E$ & $\Sigma \mathrm{Ce} / \Sigma \mathrm{Y}$ & $\mathbf{L} a_{n} / Y_{b_{n}}$ & $\mathrm{La}_{\mathbf{n}} / \mathrm{Sm}_{\mathbf{n}}$ & $\mathrm{Gd}_{\mathrm{n}} / \mathrm{Yb}_{\mathrm{n}}$ & $\left(E \mathbf{E} / \mathbf{E u}^{*}\right)_{\mathrm{n}}$ & $\left(\mathrm{Ce} / \mathrm{Ce}^{*}\right)_{\mathrm{n}}$ \\
\hline \multicolumn{8}{|c|}{ TheOxidized Zone Containing Fe-Mn Nodules } \\
\hline Petrozavodsk Bay. & 67 & 4.5 & 9.6 & 3.6 & 1.7 & 0.84 & 1.70 \\
\hline Povenetsk Bay & 152 & 4.5 & 14.1 & 4.5 & 2.1 & 0.71 & 0.99 \\
\hline Area behind Onego + Small Onego & 153 & 3.8 & 11.2 & 4.1 & 1.9 & 0.67 & 0.95 \\
\hline Big Onego + bays & 171 & 4.4 & 13.7 & 4.1 & 2.3 & 0.66 & 0.97 \\
\hline Central Onego & 167 & 4.1 & 12.2 & 3.9 & 2.0 & 0.66 & 1.05 \\
\hline South Onego & 157 & 3.7 & 9.6 & 3.8 & 1.8 & 0.67 & 1.14 \\
\hline \multicolumn{8}{|c|}{ Ore FM Nodule Horizon } \\
\hline Petrozavodsk Bay & 364 & 18.0 & 29.7 & 6.3 & 3.3 & 0.69 & 3.35 \\
\hline Big Onego + bays & 147 & 5.4 & 18.6 & 5.0 & 2.6 & 0.67 & 0.92 \\
\hline Central Onego & 149 & 5.1 & 15.6 & 4.6 & 2.3 & 0.65 & 0.96 \\
\hline South Onego & 154 & 4.9 & 8.3 & 3.6 & 1.6 & 0.64 & 1.84 \\
\hline Lake Surgubskoe & 245 & 7.6 & 26.5 & 6.1 & 2.8 & 0.77 & 1.16 \\
\hline Lake Shotozero & 100 & 6.4 & 12.4 & 4.12 & 1.9 & 0.71 & 1.53 \\
\hline Lake Shotozero Fe-Mn crust & 304 & 8.3 & 23.3 & 5.9 & 2.6 & 0.75 & 1.23 \\
\hline \multicolumn{8}{|c|}{ Rocks of the Water Catchment Area of Lake Onego } \\
\hline Granites AR-PR & 274 & 13.2 & 6.72 & 1.77 & 4.03 & 0.52 & 1.04 \\
\hline Paleo PR volcanic-sedimentary rocks & 95 & 1.4 & 0.34 & 0.44 & 1.24 & 0.99 & 1.03 \\
\hline Lake Shungite rocks & 43 & 2.2 & 0.68 & 1.03 & 0.76 & 0.71 & 0.95 \\
\hline RPSC (clay + siltstone) & 189 & 3.7 & 8.9 & 3.7 & 1.6 & 0.70 & 0.98 \\
\hline
\end{tabular}

Index " $\mathrm{n}$ " indicates that chondrite normalized contents are used. *-here $\left(\mathrm{Ce} / \mathrm{Ce}^{*}\right)_{n},\left(\mathrm{Eu} / \mathrm{Eu}^{*}\right)_{\mathrm{n}}$ are calculated respectively as $\left(\mathrm{Ce}_{\text {sample }} / \mathrm{Cen}\right) / \sqrt{ }\left(\mathrm{La}_{\text {sample }} / \mathrm{La}_{\mathrm{n}}\right)\left(\mathrm{Pr}_{\text {sample }} / \mathrm{Pr}_{\mathrm{n}}\right)$ and $\left(\mathrm{Eu}_{\text {sample }} / \mathrm{Eu}_{\mathrm{n}}\right) / \sqrt{ }\left(\mathrm{Sm}_{\text {sample }} / \mathrm{Sm}_{\mathrm{n}}\right)\left(\mathrm{Gd}_{\text {sample }} / \mathrm{Gd}_{\mathrm{n}}\right)$.

Rationing chondritis [41] during the spectral construction of REE distribution in FMF and European clay slate (EuS) [42] is done in order to describe the fractionation of REE in the bottom sediments of Lake Onego, located on the Russian platform, and this more clearly allows for the assessment the contribution of the sedimentary cover of the Russian Plate. According to values $\Sigma \mathrm{Ce} / \Sigma \mathrm{Y}(\geq 4)$, all FMF of lakes were formed in a humid sedimentary environment. For all the abovementioned $\mathrm{Fe}-\mathrm{Mn}$ formations, distinct negative $\mathrm{Eu}\left(\mathrm{Eu} / \mathrm{Eu}^{*}\right.$ value $\left.\sim 0.7\right)$ and positive Ce anomalies are typical. The most extreme values of a positive Ce anomaly are typical for the FMN of Petrozavodsk bay and Lake Shotozero. In this case, a strong positive correlation of the Ce anomaly with the amount of Mn in the FMF was observed.

Normalized by EuS, the REE distribution spectra in FMN in the main part of the water catchment area of Lake Onego are homogeneous and characterized by the depletion of heavy lanthanides-that is, an oblique spectrum falling into the region of heavy lanthanides (Figure 11). A comparison with REE spectra in catchment rocks (Precambrian crystalline rocks (granites, gneisses) and clay deposits of the phanerozoic of the Russian Platform (RPSC [42])) is shown in the graph. This is typical for rocks of continental drift. The FMN of Petrozavodsk bay and Fe-Mn nodules and crusts of Lakes Shotozero and Surgubskoe have a sharp slope in the spectrum, with a strong predominance of light lanthanides, while the FMN of South Lake Onego have a flat slope. 


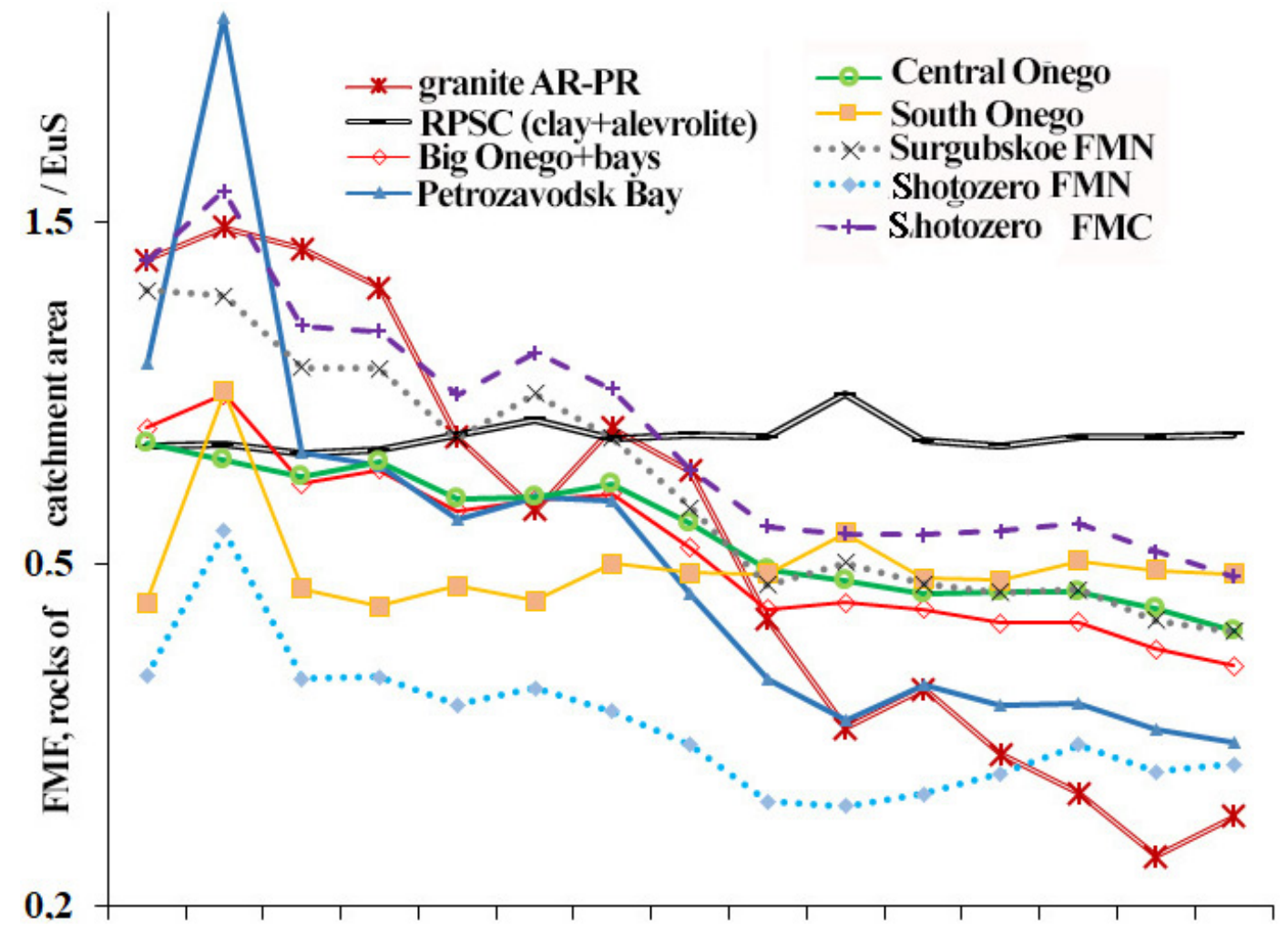

La Ce Pr Nd Sm Eu Gd Tb Dy

Figure 11. European slate-normalized [42] average REE contents in Fe-Mn nodules (FMN) in Lake Onego, Shotozero and Surgubskoe sediments that were sampled in different parts of the Lake Onego water area, in comparison with REE spectra normalized by European slate in catchment rocks (Precambrian crystalline rocks (granites, gneisses) and clay deposits of the phanerozoic of the Russian Platform (RPSC [43])).

\section{Discussion}

A comparison of the abovementioned SEM data with the analytical results of the study of FMF from lakes by atomic absorption, ICP-MS, X-ray diffraction, and X-ray diffractometry made it possible to identify some patterns. FMFs in the bottom sediments of Lake Onego were formed in the lower part of the oxidized zone of sediment, the thickness of which varies from 5 to $35 \mathrm{~cm}$. Vertical profiles of FMF of the bottom sediments of Lake Onego exhibited clearly separated layers, with a sharp and narrow Mn peak and a broader Fe-rich interval underneath (see Figures 2 and 3). FMF formation must have been caused by early diagenetic processes during the mineralization of organic matter in the sediment. Oxygen concentrations near the bottom waters of Lake Onego varied at around $0.37 \mathrm{mmol} \cdot \mathrm{L}^{-1}$ throughout the year, and the low value of $C_{\text {org }}$ allowed a high penetration of $\mathrm{O}_{2}$ into the sediment. During processes of post sedimentary change in precipitation, organic matter is oxidized with the absorption of free $\mathrm{O}_{2}$, and then $\mathrm{Fe}(\mathrm{III})$ and $\mathrm{Mn}(\mathrm{IV})$, as the most important electron acceptors for the anaerobic mineralization of $C_{\text {org }}[1,5,10,11,17]$. As a result, soluble $\mathrm{Mn}^{2+}$ ions are formed, which enter the pore water and migrate up the section to the layer in the already-formed sediment, where free $\mathrm{O}_{2}$ is not yet used up for the oxidation of organic matter. The oxidation of $\mathrm{Mn}^{2+}$ to insoluble $\mathrm{Mn}^{4+}$ occurs due to the formation of a layer with a concentration significantly higher than its content above and below. The difference in the stabilization zones of Mn and Fe determines the separation of these elements. Even minor changes in the $\mathrm{Eh}$ and $\mathrm{pH}$ of the medium lead to large changes in $\mathrm{Mn} / \mathrm{Fe}$ ratio [44]. In the manganese microconcretion layer of Lake Onega sediments, Mn content is, on average, $6.8 \%$ at a ratio of $\mathrm{Mn} / \mathrm{Fe}=1$, and maximal $\mathrm{Mn}$ content can reach $20 \%$ at an $\mathrm{Mn} / \mathrm{Fe}$ ratio = 1.6. In the formed layer of the Mn-rich microconcretion, the Mn amount exceeds its content in other 
layers of lake sediments by more than 50 times (located above and below this microlayer). In the Fe microlayer of the FMF, Fe content is, on average, $42 \%$ with an Mn/Fe ratio $=0.02$ (maximal Fe content is $68 \%$ with $\mathrm{Mn} / \mathrm{Fe}=0.001)$. In the initial bottom oxidized layer of liquid sludge, $\mathrm{Mn} / \mathrm{Fe}=$ 0.12 (maximal content in Petrozavodsk bay is $\mathrm{Mn} / \mathrm{Fe}=0.34$ ) because $\mathrm{Mn}$ microconcretions are formed exclusively with Mn minerals (sometimes they only capture diatom valves), have perfect spherical shapes, and form in surface liquid sludge or in a geochemically active environment. In oxidized zones, there is a sufficient amount of reactive organic matter, mixing of sedimentary matter, and the supply of ore elements from the water column and from the lower sediment layers is caused by diffusion in pore water along the concentration gradients upward and downward in the sediment. It is assumed that Mn microconcretions are formed as a product of diagenetic transformations in precipitation. As materials, they use mineral phases of manganese entering the waters of lakes as a suspension, dissolved from the lower sediment layers. A local feature of the granular ore layer is the abundance of diatom valves or their fragments in almost all opal samples; often, the mineralization of organic compounds remains and, for the most part, their irregular shape is maintained.

The rather significant sediment accumulation rates of Lake Onego [39] may lead to separation from the redox interface and subsequent burial accumulation in the microlayers of Mn (pyrolusite or rhodochrosite) and $\mathrm{Fe}$ (vivianite or siderite) underneath the upper sediment, where $\mathrm{O}_{2}$ is undetectable.

All oolitic and coin-type FMC of Lakes Surgubskoe and Shotozero are composed of shell-spherical collomorphic formations with a zonal phase sequence, varying degrees of crystallinity, water cut, and the predominance of homogeneous phases of Mn or Fe. They are mainly localized on the bottom surface or in the surface-oxidizing part of the sediment at the water-bottom border between sections. Fe sharply prevails over Mn in the middle part of the nodules. Homogeneous mineral phases of Mn are present in the core and in the form of small grains, often contouring the Fe zones. The rest of the nodule substance often has a mixed composition with areas of slight predominance of either iron or manganese. Grains of terrigenous minerals are quartz, feldspars, chlorite; fragments of earlier nodules transformed during the diagenesis (mineral composition of rhodochrosite, siderite) act as nodule cores. The accumulation of ore material is accompanied by the capture of grains of terrigenous minerals throughout the whole sediment deposition process. In the composition of FM crusts of Lake Shotozero, fragments and entire FM nodules composed of siderite or rhodochrosite are even more abundant (Figure 12). Often, crust layers and nodules that are enclosed in them are later crossed by cracks that are filled with rhodochrosite. The chemical composition of the FMC of small lakes, their morphology and localization in the bulk and the constant presence of fragments of fossilized glycocalyx with manganese compounds indicates that they were formed as a result of colloidal chemical and microbiological processes. High concentrations of Ba observed in almost all the studied manganese zones of nodules and crusts of Lakes Surgubskoe and Shotozero could also be associated with zones of high biological productivity [42]. The inflow of iron and manganese during the growth of nodules and crusts occurs not only from the water body itself, but is also associated with the processes of remobilization from bottom sediments at the stage of development of early diagenesis.

The presence of mineralized microflora in larger FMF (from $1 \mathrm{~mm}$ to $1 \mathrm{~cm}$ ) from the bottom sediments of Petrozavodsk bay and FMC (up to $10 \mathrm{~cm}$ ) of Lakes Surgubskoe and Shotozero, is testament to the major contribution of the microbiologic oxidation of $\mathrm{Mn}$ and Fe during nodule formation.

A review of the composition of the studied FMN samples of Lakes Onego, Surgubskoe, and Shotozero shows that all FMN were highly enriched with oxides and hydroxides of manganese and iron, relative to sedimentary rocks. At the same time, $\mathrm{Ba}, \mathrm{Ce}, \mathrm{Mo}, \mathrm{Ph}$, and $\mathrm{Hg}$ elements, as well as all other macro- and trace elements, were depleted. Manganese nodules and microconcretions are most enriched with $\mathrm{Ba}, \mathrm{Ce}$, and $\mathrm{Hg}$, while granular microformations of Lake Onego are enriched with $\mathrm{Ph}$ and Mo. Only FMC of Petrozavodsk bay and Lake Surgubskoe are also enriched in light REE, Co, and $\mathrm{Cd}$, the contents of which are still, however, not comparable with those in oceanic and marine nodules. Nodules from freshwater lakes are enriched relative to sedimentary rocks by single elements [20]. This is associated with the high growth rates of FMC in lakes, poor diffusion of metals from underlying 
sediments during their limited exposure on the bottom surface and rapid submergence. The obtained data show that intensively occurring natural processes of precipitation and early diagenesis, leading to the formation of FMC, are able to determine their extremely poor trace element composition.

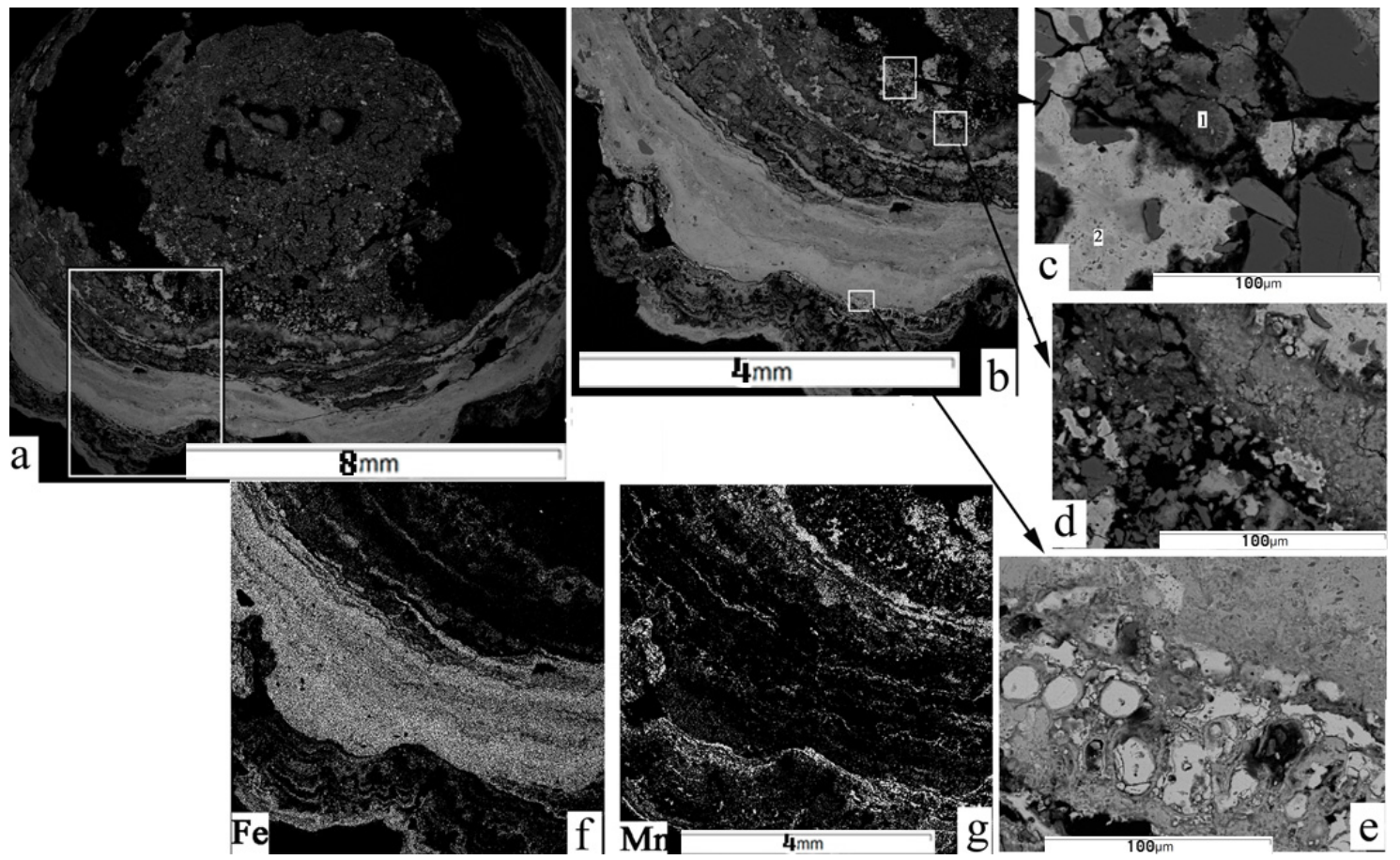

Figure 12. Photo of ferromanganese (FM) nodule from Lake Surgubskoe's sediments (a), made using an electron microscope MIRA-3; (b-e) - fragments FM nodule composed of siderite (1) or rhodochrosite (2) and (f,g) areal scanning of Fe and Mn concentrations (C, O, Ba, Al, P, Si, Na, K, Ca) in FM nodule fragments (b) made with SEM.

A comparison of the average REE contents and the spectrum of their FMN distribution from different regions of Lake Onego and small lakes with REE prevalence in the main types of rocks of the Baltic Crystalline Shield and sedimentary deposits of the Russian Platform, in the water of the catchment area of Lake Onego [39,41-43], allows us to make the following conclusions with regard to their lithogeochemical features and formation environments. REE content in the microconcretions of Lake Onego and the FMC of small lakes is lower than those of the host bottom sediments, with the exception of the FMF of Petrozavodsk bay and Lake Surgubskoe. Crystalline rocks of the Baltic Crystalline Shield typically have high LREE/HREE ratios and a distinct negative Eu anomaly. With $\mathrm{La}_{\mathrm{N}} / \mathrm{Yb}_{\mathrm{N}}>8$ (and according to a steep slope of the spectrum), one can conclude that acid igneous formations predominate in the studied region. High $(\geq 20) \mathrm{La}_{N} / \mathrm{Yb}_{\mathrm{N}}$ ratios indicate dominance in the paleowater catchment areas of granitoids [45-47]. The steep slope of the REE spectrum, high $\mathrm{La}_{\mathrm{N}} / \mathrm{Yb}_{\mathrm{N}}$ ratios, and the presence of a negative Eu anomaly are typical for the FMC of the Petrozavodsk bay of Lakes Onego and Surgubskoe. This indicates the predominance of Precambrian crystalline rocks (granites, gneisses) among the source areas. Spectra similar to REE in clayey rocks of the Russian Platform cover, in almost complete agreement with values of the considered indicator ratios of lanthanides, with the exception of the Ce anomaly, were revealed for the South Onego FMFs. This indicates that the source of REE in the studied Fe-Mn nodules and crusts is a suspended substance coprecipitating on manganese and iron oxyhydroxides, and in the initial suspension composition, with a significant role belonging to the erosion products of rocks in the catchment areas. A fairly pronounced trend was revealed in the change in the distribution of the REE spectrum for FMFs over the waters of Lake Onego, with a gradual increase in the role of sedimentary rocks of the Russian Platform to South Onego as sources of sedimentary substances. It is revealed that the studied features 
of the FMN of Petrozavodsk bay in Lakes Onego and Surgubskoe practically coincide. This confirms that the suspended matter brought in by the Shuya river is the main constructional material of the bottom sediments and FMF of Petrozavodsk bay. The formation of a pronounced positive Ce anomaly occurs because of sorption by manganese oxides of FMN Ce in almost all the studied samples, as well as light lanthanides in Petrozavodsk bay and Lake Surgubskoe. This also indicates the hydrogenation of the FMC material.

\section{Conclusions}

A comparison was made between the original data on the basic and microelement composition of Fe-Mn nodules from bottom sediments of various water areas of Lake Onego and from the bottom of two small lakes located within its water catchment area. The average element contents and variations in their concentrations in the FMC were determined; similarities and differences in their microelements were revealed. All FMFs of Lakes Onego, Surgubskoe, and Shotozero have increased contents of $\mathrm{Ba}, \mathrm{Ce}, \mathrm{Mo}, \mathrm{P}$ and $\mathrm{Hg}$ elements relative to underlying or host bottom sediments. For other studied elements, FMN concentrations were significantly reduced compared to their level in the bottom sediment. In all bottom sediments of Lake Onego, the ore-bearing layer has a zonal structure: (1) upper thinnest ( $<3 \mathrm{~mm}$ ) Mn-rich layer, and (2) slightly thicker (up to $2 \mathrm{~cm}$ ) Fe-rich layer under it. The Mn-rich layer was composed of separate Mn microconcretions with diatom valves, Fe illite or Fe chlorite, and terrigenous mineral grains. Below the Mn-rich microlayer is a microlayer formed by goethite, shell-spherical collomorphic formations with different morphologies and crystallinity degree formations, from microconcretions to fine-needle, leafy crystals, and pseudomorphs in organic remains in association with diatom valves, Fe illite and Fe chlorite, and grains of terrigenous materials. FMF formation and their diagenesis are accompanied by the separation of Mn and Fe mineral phases. Separate zones that are rich in Fe and Mn are formed. The presence of the mineralized remains of microflora in larger FMFs (from $1 \mathrm{~mm}$ to $1 \mathrm{~cm}$ ) from the bottom sediments of Petrozavodsk bay and the FMN (up to $10 \mathrm{~cm}$ ) of Lakes Surgubskoe and Shotozero is testament to the major contribution of microbiological Mn and Fe oxidation during nodule formation.

The chemical composition, morphology, and localization of the FMF of the studied lakes indicated that $\mathrm{Mn}$ microconcretions are formed as a product of diagenetic transformations in precipitation. As a material, they use mineral phases of manganese, entering the waters of lakes with suspensions dissolved from the lower sediment layers. The mobility of the FMF element in diagenesis can be characterized by the ratio of its contents in microconcretions relative to the host bottom sediment. As a result of diagenetic changes in the microlayer of Mn microconcretions, the value of Mn/Fe increased by more than 10 times, and microelement composition changed (Ba and Ce enrichment). A pronounced positive Ce anomaly present in almost all REE spectra of FMF from the studied lakes also indicates the hydrogenic factors of these materials.

Rather high rates of sediment accumulation in Lake Onega contributed to the fact that layers enriched with Fe-Mn are submerged in the sediment with a continuing lag in the dynamics of the dissolution-deposition of Fe/Mn oxides. Under anaerobic conditions, buried Mn- and Fe-enriched layers were converted into separate microlayers of reduced Fe and Mn phases (pyrolusite, vivianite, siderite, and rhodochrosite).

Author Contributions: Conceptualization, V.S., D.S.; methodology, N.B., D.S.; software, N.E., E.O.; validation, V.S., D.S., N.B.; formal analysis, N.E.; investigation, All authors; resources, V.S., D.S.; data curation, V.S., N.B., N.E.; writing-original draft preparation, V.S.; writing-review and editing, V.S.; visualization, V.S.; supervision, V.S.; project administration, D.S. All authors have read and agreed to the published version of the manuscript.

Funding: The main part of the work, concerned with field research, sample preparation for chemical analytical work and results interpretation, was financially supported by a grant from the Russian Science Foundation No. 18-17-00176; studies and analytical determinations of REE and results interpretation were done with financial support from Russian Foundation for Fundamental Research project No. 19-05-50014.

Conflicts of Interest: The authors declare no conflict of interest. 


\section{References}

1. Strakhov, N.; Brodskaya, N.; Knyazeva, L.; Razzhivina, A.; Rateev, M.; Sapozhnikov, D.; Shishova, E. Sediments Formation in Modern Reservoirs; Publishing House of the USSR AS: Moscow, Russia, 1954; p. 792. (In Russian)

2. Baturin, G. Geochemistry of Manganese and Manganese Nodules in the Ocean; D. Reidel Publishing Company: Dordrecht, The Netherlands, 1988; p. 342.

3. Kholodov, V.N.; Nedumov, R.I.; Golubovskaya, E.V. Facies types of sedimentary iron ore deposits and their geochemical features: Communication 1. Facies groups of sedimentary ores, their lithology, and genesis. Lithol. Miner. Resour. 2012, 47,447-472. [CrossRef]

4. Kuleshevich, L.V.; Lar'kina, N.J.; Inina, I.S. Iron minerals in the collection of the Museum of Precambrian Geology: Limonite and hematite ores of Karelia. Geol. Miner. Resour. Karelia 2010, 13, 131-138. (In Russian)

5. Baturin, G. Ores of the Ocean; Nauka: Moscow, Russia, 1993; p. 306. (In Russian)

6. Dubinin, A.V.; Uspenskaya, T.Y.; Rimskaya-Korsakova, M.N.; Demidova, T.P. Rare elements and Nd and Sr isotopic composition in micronodules from the Brazil Basin, Atlantic Ocean. Lithol. Miner. Resour. 2017, 52, 81-101. [CrossRef]

7. Baturin, G.N.; Granina, L.Z. Rare earth elements in the ferromanganese formations of Lake Baikal. Dokl. Earth Sci. 2009, 428, 1208-1211. [CrossRef]

8. Granina, L.Z.; Mats, V.D.; Phedorin, M.A. Iron-manganese formations in the Baikal region. Russ. Geol. Geophys. 2010, 51, 650-660. [CrossRef]

9. Granina, L.Z.; Zakharova, Y.P.; Parfenova, V.V. Biogenic Fe and Mn accumulation in the bottom sediments of Lake Baikal. Geochem. Int. 2011, 49, 1154-1160. [CrossRef]

10. Och, L.M.; Müller, B.; Voegelin, A.; Ulrich, A.; Göttlicher, J.; Steiniger, R.; Mangold, S.; Vologina, E.G.; Sturm, M. New insights into the formation and burial of Fe/Mn accumulations in Lake Baikal sediments. Chem. Geol. 2012, 330-331, 244-259. [CrossRef]

11. Och, L.M.; Müller, B.; Wichser, A.; Ulrich, A.; Vologina, E.G.; Sturm, M. Rare earth elements in the sediments of Lake Baikal. Chem. Geol. 2014, 376, 61-75. [CrossRef]

12. Dobrovolski, V. Basics of Biogeochemistry; Akademija: Moscow, Russia, 2003; p. 400. (In Russian)

13. Dauval'ter, V.A.; Il'yashuk, B.P. Conditions of formation of ferromanganese nodules in the bottom sediments of lakes in the Baltic shield. Geochem. Int. 2007, 45, 615-619. [CrossRef]

14. Strakhov, N. Accumulation and distribution of ferromanganese group elements. In The Chemistry of the Ocean; Nauka: Moscow, Russia, 1979; Volume 2, pp. 131-164. (In Russian)

15. Lisitzin, A. Processes of Ocean Sedimentation; Nauka: Moscow, Russia, 1978; p. 392. (In Russian)

16. Volkov, I. Redox processes in bottom sediment diagenesis. Ferromanganese nodules. In The Chemistry of the Ocean; Nauka: Moscow, Russia, 1979; Volume 2, pp. 363-468. (In Russian)

17. Kholodov, V. Geochemistry of the Sedimentary Process; GEOS: Moscow, Russia, 2006; p. 608. (In Russian)

18. Shkol'nik, E.; Zhegallo, E.; Baturin, G.; Bogatyrev, B.; Gaber, M.; Gerasimenko, L.; Golovin, D.; Eganov, E.; Elen', S.; Yin, L.; et al. Scanning Electron Microscopy Study of Manganese and Ferromanganese Mineralization in Different Environments; Jeslan: Moscow, Russia, 2012; p. 472. (In Russian)

19. Zavarzin, G. Lectures on Natural History Microbiology; Nauka: Moscow, Russia, 2012; p. 348. (In Russian)

20. Baturin, G.N. Distribution of Elements in Ferromanganese Nodules in Seas and Lakes. Lithol. Miner. Resour. 2019, 54, 362-373. [CrossRef]

21. Semenovich, N. Bottom Sediments of Lake Onega; Nauka: Leningrad, Russia, 1973; p. 104. (In Russian)

22. Moore, W.S. Iron-manganese banding in Oneida ferromanganese nodules. Nature 1981, 292, $233-235$. [CrossRef]

23. Morozov, A.A. The mechanism of iron and manganese fixing at the surface of ferromanganese nodules. Dokl. AS USSR 1985, 282, 688-692. (In Russian)

24. Dubinin, A.V.; Uspenskaya, T.Y.; Gavrilenko, G.M.; Rashidov, V.A. Geochemistry and genesis of Fe-Mn mineralization in island arcs in the west Pacific Ocean. Geochem. Int. 2008, 46, 1206-1227. [CrossRef]

25. Glushanin, L.; Sharov, N. The Onega Paleoproterozoic Structure (Geology, Tectonics, Deep Structure and Mineralogy); Glushanin, L., Sharov, N., Shtiptsov, V., Eds.; KarNTS RAN: Petrozavodsk, Russia, 2011; p. 431. (In Russian)

26. Biske, G.; Lac, G.; Lukashov, A.; Goryunova, N.; Il'in, V. The Structure and History of the Basin of Lake Onega; Karelia: Petrozavodsk, Russia, 1971; p. 73. (In Russian) 
27. Kvasov, D.D. The Late-Quaternary history of large lakes and inland seas of eastern Europa; Nauka: Leningrad, Russia, 1975; p. 278. (In Russian)

28. Demidov, I.N. Identification of marker horizon in bottom sediments of the Onega periglacial lake. Dokl. Earth Sci. 2006, 407, 213-216. [CrossRef]

29. Subetto, D. Bottom Sediments of Lakes: Paleolimnological Reconstructions; Herzen, A.I., Ed.; Publishing House of the Russian State Pedagogical University: St. Petersburg, Russia, 2009; p. 348. (In Russian)

30. Subetto, D.A.; Potakhin, M.S.; Zobkov, M.B.; Tarasov, A.Y.; Shelekhova, T.S.; Gurbich, V.A. Lake Onego development in the late glacial assessed with the use of GIS technologies. Geomorphol. RAS 2019, 3, 83-90. [CrossRef]

31. Zobkov, M.; Potakhin, M.; Subetto, D.; Tarasov, A. Reconstructing Lake Onego evolution during and after the Late Weichselian glaciation with special reference to water volume and area estimations. J. Paleolimnol. 2019, 62, 53-71. [CrossRef]

32. Hang, T.; Gurbich, V.; Subetto, D.; Strakhovenko, V.; Potakhin, M.; Belkina, N.; Zobkov, M. A local clay-varve chronology of Onega Ice Lake, NW Russia. Quat. Int. 2019, 524, 13-23. [CrossRef]

33. Fillipov, M.; Melezhik, V. Atlas of Textures and Structures of Shungite-Bearing Rocks of the Onega Synclinorium; Fillipov, M., Melezhik, V., Eds.; KarNTS RAN: Petrozavodsk, Russia, 2006; p. 80. (In Russian)

34. Svetov, S.; Gogolev, M. Current Problems of Precambrian Geology, Geophysics and Geoecology. In Proceedings of the XXVI Youth Scientific School-Conference Dedicated to the Memory of Corresponding Member of the USSR Academy of Sciences K.O. Kratts, and academician F.P. Mitrofanov, Petrozavodsk, Russia, 12-16 October 2015; Svetov, S., Gogolev, M., Egorova, S., Eds.; KarNTS RAN: Petrozavodsk, Russia, 2015; p. 204.

35. Belkina, N.A.; Subetto, D.A.; Efremenko, N.A.; Kulik, N.V. Features of microelements distribution in a blanket of Lake Onego bottom sediments. Naukaiobrazovanie 2016, 3, 135-139. (In Russian)

36. Rossolimo, L. Basics of lakes typification and limnological zoning. In Matter Accumulations in Lakes: Sborniknauchnyhtrudov; Nauka: Moscow, Russia, 1964; pp. 3-12. (In Russian)

37. Onego Lake. Atlas; Filatov, N., Ed.; KarNTS RAN: Petrozavodsk, Russia, 2010; p. 151. (In Russian)

38. Strakhovenko, V.; Subetto, D.; Hang, T.; Ovdina, E.; Danilenko, I.; Belkina, N.; Potakhin, M.; Zobkov, M.; Gurbich, V. Mineral and geochemical composition of the Onega Ice Lake sediments. Baltica 2019, 31, 165-172. [CrossRef]

39. Strakhovenko, V.; Subetto, D.; Ovdina, E.; Danilenko, I.; Belkina, N.; Efremenko, N.; Maslov, A. Mineralogical and Geochemical composition of Late Holocene bottom sediments of Lake Onego. J. Great Lakes Res. 2020, in press. [CrossRef]

40. Pal'chik, N.A.; Grigor'eva, T.N.; Moroz, T.N. Natural and synthetic manganese minerals. Russ. J. Inorg. Chem. 2013, 58, 138-143. [CrossRef]

41. Taylor, S.; McLennan, S. The Continental Crust: Its Composition and Evolution. In An Examination of the Geochemical Record Preserved in Sedimentary Rocks; Mir: Moscow, Russia, 1988; p. 384. (In Russian)

42. Sun, S.; McDonough, W. Chemical and isotopic systematics of oceanic basalts: Implications for mantle composition and processes. In Magmatism in the Ocean Basins; Saunders, A., Norry, M., Eds.; Cambridge University Press: Cambridge, UK, 1989; Volume 42, pp. 313-345.

43. Ronov, A.B.; Migdisov, A.A. Quantitative regularities of structure and composition of sedimentary strata of the East European platform and the Russian plate and their place among the ancient platforms of the world. Lithol. Miner. Resour. 1996, 5, 451-475. (In Russian)

44. Martynova, M.V. Manganese species and their content and transformation in freshwater sediments (analytical review). EkologicheskayaKhimiya 2012, 21, 38-52.

45. Varentsov, I.M.; Dritc, V.A.; Gorshkov, A.I.; Andreev, J.K. Mn-Fe Atlantic crusts: Geochemistry of rare earth elements, aspects of genesis (Krylov seamount). Lithol. Miner. Resour. 1989, 5, 24-36. (In Russian)

46. Maslov, A.V.; Shevchenko, V.P.; Ronkin, Y.L.; Lepikhina, O.P.; Novigatsky, A.N.; Filippov, A.S.; Shevchenko, N.V. Peculiarities of the rare-earth element distribution in the modern bottom sediments of the White Sea and the lower reaches of the Severnaya Dvina River. Oceanology 2013, 53, 702-714. [CrossRef]

47. Felitsyn, S.B.; Bogomolov, E.S. Rare earth elements and Rb-Sr and Sm-Nd systematics in the peat bog iron ore and moss of the NW East European Platform. Lithol. Miner. Resour. 2016, 51, 107-116. [CrossRef]

(C) 2020 by the authors. Licensee MDPI, Basel, Switzerland. This article is an open access article distributed under the terms and conditions of the Creative Commons Attribution (CC BY) license (http://creativecommons.org/licenses/by/4.0/). 